SUZANA SIKUSAWA

Prevalência e caracterização epidemiológica da brucelose bovina no Estado de Santa Catarina

São Paulo

2004 
SUZANA SIKUSAWA

\section{Prevalência e caracterização epidemiológica da brucelose bovina no Estado de Santa Catarina}

Dissertação apresentada ao Programa de Pósgraduação em Epidemiologia Experimental e Aplicada às Zoonoses da Faculdade de Medicina Veterinária e Zootecnia da Universidade de São Paulo para obtenção do título de Mestre em Medicina Veterinária

Departamento:

Medicina Veterinária Preventiva e Saúde Animal

Área de concentração:

Epidemiologia Experimental e Aplicada às Zoonoses

Orientador:

Prof. Dr. Fernando Ferreira

São Paulo 
Autorizo a reprodução parcial ou total desta obra, para fins acadêmicos, desde que citada a fonte.

DADOS INTERNACIONAIS DE CATALOGAÇÃO-NA-PUBLICAÇÃO

(Biblioteca da Faculdade de Medicina Veterinária e Zootecnia da Universidade de São Paulo)

T.1370

FMVZ
Sikusawa, Suzana

Prevalência e caracterização epidemiológica da brucelose bovina no Estado de Santa Catarina / Suzana Sikusawa. -- São Paulo : S. Sikusawa, 2004.

$107 \mathrm{f}$ : : il.

Dissertação (mestrado) - Universidade de São Paulo. Faculdade de Medicina Veterinária e Zootecnia. Departamento de Medicina Veterinária Preventiva e Saúde Animal, 2004.

Programa de Pós-graduação: Epidemiologia Experimental e Aplicada às Zoonoses.

Área de concentração: Epidemiologia Experimental e Aplicada às Zoonoses.

Orientador: Prof. Dr. Fernando Ferreira.

1. Brucelose animal. 2. Bovinos. 3. Prevalência. 4. Santa Catarina. 5. Brasil. I. Título. 
UNIVERSIDADE DE SÃO PAULO Faculdade de Medicina Veterinária e Zootecnia

Cidade Universitária "Armando de Salles Oliveira” Comissão Bioética

\section{CERTIFICADO}

Certificamos que o Projeto intitulado "Prevalência e caracterização epidemiológica da brucelose bovina no Estado de Santa Catarina" Protocolo $n^{\circ} 279 / 2003$, utilizando apenas amostras de soro de vacas, sob a responsabilidade do Prof. Dr. Fernando Ferreira, está de acordo com os princípios éticos de experimentação animal da Comissão de Bioética da Faculdade de Medicina Veterinária e Zootecnia da Universidade de São Paulo e foi aprovado "ad referendun".

(We certify that the Research "Prevalence and epidemiologic characterization of the bovine brucellosis in the State of Santa Catarina" protocol number 279/2003, utilizing just sample serum of the bovines, under the responsibility of Prof. Dr. Fernando Ferreira, agree with Ethical Principles in Animal Research adopted by Biotic Commission of the Faculty of Veterinary Medicine and Zootechny of University of São Paulo and was approved "ad referendun").

São Paulo, 29 de abril de 2003

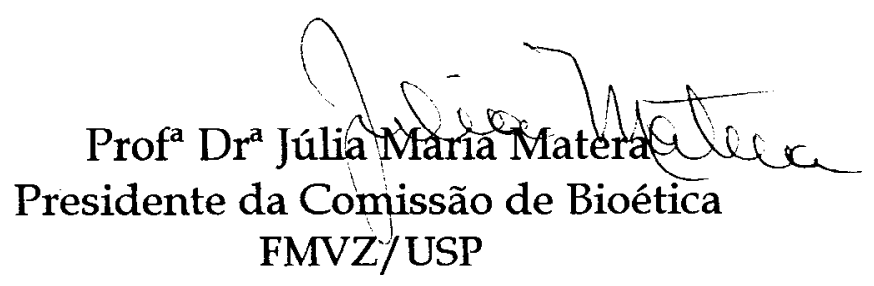

Av. Prof. Dr. Orlando Marques de Paiva, 87 - 05508-000 - Cid. Univ. "Armando de Salles Oliveira" Fones: (011) 3091-7671/3091-7676 Fax: (011) 3032-2224 


\section{FOLHA DE AVALIAÇÃO}

Nome do autor: SIKUSAWA, Suzana

Título: Prevalência e caracterização epidemiológica da brucelose bovina no Estado de Santa Catarina

Dissertação apresentada ao Programa de Pósgraduação em Epidemiologia Experimental e Aplicada às Zoonoses da Faculdade de Medicina Veterinária e Zootecnia da Universidade de São Paulo para obtenção do título de Mestre em Medicina Veterinária

Data:

Banca examinadora

Prof. Dr.

Instituição:

Assinatura: Julgamento:

Prof. Dr. Instituição:

Assinatura: Julgamento:

Prof. Dr. Instituição:

Assinatura: Julgamento: 


\section{DEDICATÓRIA}

Dedico à toda minha família:

Meupai,

que embora ausente fisicamente, permanece em meu coração;

Minha mãe,

que sempre está do meu lado, em qualquer circunstância;

Meu irmão Yuji e minha cunbada Sui,

que sempre estão prontos a me incentivar;

Minha irmã Marcinha e meu cunbado Lins, que sempre estão prontos a me ajudar;

Meus três sobrinhos, Guilherme, Thiago e Ana Flávia, que são a alegria da casa;

Meu cachorro Danny e meu gato Nick, que já se foram, mas vão ser sempre lembrados e

Men gato Tiquinho, que é o xodó da casa. 


\section{AGRADECIMENTOS}

\section{Agradecimentos mais do que especiais}

Ao meu orientador Prof. Dr. Fernando Ferreira, pelos ensinamentos e pela dedicação e paciência que foram constantes durante a realização dessa dissertação;

Ao Prof. Dr. José Soares Ferreira Neto e ao Prof. Dr. Marcos Amaku, por compartilharem um pouco de seus conhecimentos;

Ao pessoal da CID ASC, pela realização do trabalho a campo e sem o qual esta dissertação não seria possivel;

Ao CNPq, pelo apoio financeiro;

À todos do LEB, pela ótima convivência e pelo apoio e incentivo durante esse periodo, em especial:

Ao Ricardo, por estar sempre pronto a me ajudar e pela paciência em me ensinar muitas coisas;

À Patrícia, por me ajudar nos formulários, nos contatos e no que fosse necessário;

À Juliana, por me ajudar a traduzir o resumo, pela dica da capa e por ter um bom humor e um alto astral que são contagiantes $e$

À Lorena e à Jucelia, por me agüentarem durante tanto tempo e estarem sempre prontas a levantar o men astral;

Às funcionárias da biblioteca e à todos os funcionários do VPS;

À minha amiga Patrícia Koga, pela ajuda na busca de frases, por ouvir meus desabafos, pelos conselhos e por ser minha melhor amiga;

Aos meus amigos e amigas e à todos, que de uma forma ou de outra me ajudaram na realização dessa conquista e

À Deus, acima de tudo. 
"Nunca ande pelo caminho traçado, pois ele conduz somente até onde os outros foram." (Alexandre Graham Bell) 


\section{RESUMO}

SIKUSAWA, S. Prevalência e caracterização epidemiológica da brucelose bovina no Estado de Santa Catarina. [Prevalence and epidemiologic characterization of bovine brucellosis in Santa Catarina state]. 2004. $107 \mathrm{f}$. Dissertação (Mestrado em Epidemiologia Experimental e Aplicada às Zoonoses) Faculdade de Medicina Veterinária e Zootecnia, Universidade de São Paulo, São Paulo, 2004.

Com o objetivo de se conhecer a situação epidemiológica da brucelose bovina no Estado de Santa Catarina, o mesmo foi subdividido em cinco áreas epidemiológicas. Para o planejamento amostral foi utilizada a amostragem aleatória sistemática. Além do cálculo da prevalência da brucelose bovina, foi realizada a caracterização epidemiológica das propriedades em cada uma das cinco áreas e verificada a possibilidade de agrupamento de algumas delas de acordo com as semelhanças existentes. Para o estudo foram colhidas amostras de soro de 7756 animais e questionários epidemiológicos foram aplicados em 1579 propriedades. As prevalências de focos e de animais soropositivos para brucelose bovina no Estado de Santa Catarina foram 0,02\% (0,00-0,15\%) e $0,06 \% \quad(0,01-0,40 \%)$, respectivamente. Nas áreas 1 e 2, a prevalência de focos foi de 0,00\% (0,00-1,23\%); na área 3 foi de 0,00\% (0,00-0,93\%), na área 4 foi de 0,34\% (0,00-1,86\%) e na área 5 foi de $0,00 \%(0,00-1,26 \%)$. Em relação à prevalência de animais soropositivos para brucelose bovina, com exceção da área 4, cuja prevalência foi de 0,89\% $(0,13$ $5,76 \%)$, as demais áreas tiveram prevalência de 0,00\% (0,00-0,00\%). A maioria das propriedades das cinco áreas possui criação extensiva e bovinos mestiços, utiliza ordenha manual e não utiliza inseminação artificial. Com exceção da área 5, cuja maioria é de exploração leiteira, as demais são predominantemente de exploração mista. A área 3, que possui a maior mediana de produção diária de leite ( 7,5 litros), é 
a única cuja maioria das propriedades fazem o resfriamento do leite. A área 1 é a que possui maior mediana do número de bovinos (16 bovinos por propriedade). De acordo com as análises realizadas, sugere-se que as áreas 3 e 4 sejam agrupadas.

Palavras-chave: Brucelose animal. Bovinos. Prevalência. Santa Catarina. Brasil. 


\begin{abstract}
SIKUSAWA, S. Prevalence and epidemiological characterization of bovine brucellosis in Santa Catarina state. [Prevalência e caracterização epidemiológica da brucelose bovina no Estado de Santa Catarina]. 2004. 107 f. Dissertação (Mestrado em Epidemiologia Experimental e Aplicada às Zoonoses) - Faculdade de Medicina Veterinária e Zootecnia, Universidade de São Paulo, São Paulo, 2004.
\end{abstract}

For this study Santa Catarina has been divided in five epidemiological areas in order to know the epidemiological situation of bovine brucellosis in this state. Systematic random sampling was used for the sampling design. The prevalence of bovine brucellosis was determined as well as the epidemiological characterization of the farms in each of the five areas, and the possibility of grouping some of them according to existent similarity was tested. Serum samples of 7756 animals were collected and an epidemiological survey using questionnaires was carried out in 1579 farms. The prevalence of positive holdings and animals for bovine brucellosis in Santa Catarina state were $0,02 \% \quad(0,00-0,15 \%)$ and $0,06 \% \quad(0,01-0,40 \%)$, respectively. In areas 1 and 2, the prevalence of positive holdings was $0,00 \%(0,00$ $1,23 \%)$; in area 3 it was $0,00 \%(0,00-0,93 \%)$, in area 4 it was $0,34 \%(0,00-1,86 \%)$ and in area 5 it was $0,00 \%(0,00-1,26 \%)$. Regarding prevalence of serum-positive animals for bovine brucellosis, all areas had prevalence $0,00 \%(0,00-0,00 \%)$, except area 4 , which had prevalence $0,89 \%(0,13-5,76 \%)$. Most of the farms of five areas raise the animals extensively, grow mixed-breed cattle, make use of manual milking and do not use artificial insemination. The great majority of the areas develop mixed exploration except area 5 in which most farms grow dairy cattle. Area 3, which has the highest median of dairy milk production ( 7,5 liters), is the only one where the cooling of the milk is practiced in most of the farms. Area 1 has the highest median of 
number of bovine (16 bovines per farm). According to the analysis developed, it is suggested that areas 3 and 4 be grouped.

Key-words: Animal brucellosis. Bovines. Prevalence. Santa Catarina. Brazil. 


\section{LISTA DE FIGURAS}

Figura 1 - Mapa do Estado de Santa Catarina demonstrando sua subdivisão em cinco áreas epidemiológicas .....

Figura 2 - Diagrama de blocos do número total de bovinos segundo a área

Figura 3 - Diagrama de blocos do número de bovinos machos castrados/total de bovinos segundo a área

Figura 4 - Diagrama de blocos do número de bovinos machos 0 a 6 meses/total de bovinos segundo a área

Figura 5 - Diagrama de blocos do número de bovinos machos 6 a 12 meses/total de bovinos segundo a área

Figura 6 - Diagrama de blocos do número de bovinos machos $\geq 12$ meses/total de bovinos segundo a área

Figura 7 - Diagrama de blocos do número de bovinos fêmeas 0 a 6 meses/total de bovinos segundo a área

Figura 8 - Diagrama de blocos do número de bovinos fêmeas 6 a 12 meses/total de bovinos segundo a área

Figura 9 - Diagrama de blocos do número de bovinos fêmeas $\geq 12$ meses/total de bovinos segundo a área

Figura 10 - Diagrama de blocos da produção diária de leite (litros) segundo a área 


\section{LISTA DE QUADROS}

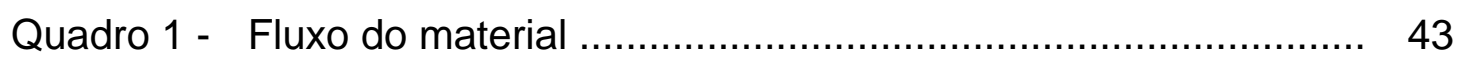

Quadro 2 - Variáveis quantitativas analisadas ................................. 50

Quadro 3 - Variáveis qualitativas analisadas .................................... 54 


\section{LISTA DE TABELAS}

Tabela 1 - Interpretação do teste do 2-ME para fêmeas com idade igual ou superior a 24 meses, vacinadas entre 3 e 8 meses de idade

Tabela 2 - $\quad$ Interpretação do teste do 2-ME para fêmeas não vacinadas e machos, com idade superior a 8 meses

Tabela 3 - Número total e amostrado de propriedades e de fêmeas bovinas com idade igual ou superior a 12 meses no Estado de Santa Catarina segundo a área

Tabela 4 - Prevalência de focos de brucelose bovina - Santa Catarina, 2001.

Tabela 5 - Prevalência de animais soropositivos para brucelose Santa Catarina, 2001

Tabela 6 - Freqüência do tipo de exploração segundo a área - Santa Catarina, 2001

Tabela 7 - Freqüência do tipo de criação segundo a área - Santa Catarina, 2001

Tabela 8 - Freqüência da raça de bovinos segundo a área - Santa Catarina, 2001

Tabela 9 - Freqüência do tipo de ordenha das propriedades leiteiras e mistas segundo a área - Santa Catarina, 2001

Tabela 10 - Freqüência do número de ordenhas das propriedades leiteiras e mistas segundo a área - Santa Catarina, 2001 .....

Tabela 11 - Freqüência de propriedades que fazem o resfriamento do leite segundo o tipo de exploração e a área - Santa Catarina, 2001

Tabela 12 - Freqüência da utilização de inseminação artificial segundo a área - Santa Catarina, 2001

Tabela 13 - Freqüência da presença de outras espécies de animais domésticos na propriedade segundo a área - Santa Catarina, 2001

Tabela 14 - Freqüência da presença de animais silvestres na propriedade segundo a área - Santa Catarina, 2001 
Tabela 15 - Ocorrência de aborto na propriedade nos 12 meses que antecederam a aplicação do questionário segundo a área Santa Catarina, 2001

Tabela 16 - Destino do feto abortado e da placenta segundo a área Santa Catarina, 2001

Tabela 17 - Freqüência de compra e venda de bovinos com finalidade de reprodução segundo a área - Santa Catarina, 2001 .......

Tabela 18 - Origem da compra de bovinos com finalidade de reprodução segundo a área - Santa Catarina, 2001

Tabela 19 - Destino da venda de bovinos com finalidade de reprodução segundo a área - Santa Catarina, 2001

Tabela 20 - Freqüência de tipos de manejo utilizados nas propriedades segundo a área - Santa Catarina, 2001

Tabela 21 - Local de abate das propriedades de corte e mista segundo a área - Santa Catarina, 2001

Tabela 22 - Destino do leite das propriedades leiteiras segundo a área Santa Catarina, 2001

Tabela 23 - Freqüência de entrega de leite a granel das propriedades leiteiras segundo a área - Santa Catarina, 2001

Tabela 24 - Freqüência da produção de queijo e/ou manteiga e sua finalidade nas propriedades leiteiras segundo a área Santa Catarina, 2001

Tabela 25 - Freqüência do consumo de leite cru segundo a área - Santa Catarina, 2001

Tabela 26 - Realização de testes para diagnóstico da brucelose segundo a área - Santa Catarina, 2001

Tabela 27 - Regularidade dos testes para diagnóstico da brucelose segundo a área - Santa Catarina, 2001

Tabela 28 - Realização de vacinação de bovinos contra a brucelose segundo a área - Santa Catarina, 2001

Tabela 29 - Freqüência de propriedades que possuem assistência veterinária e tipo de assistência veterinária segundo a área - Santa Catarina, 2001 


\section{LISTA DE ABREVIATURAS E SIGLAS}

2- ME 2-mercaptoetanol

ADR Administração regional

AAT Antígeno acidificado tamponado

CEDISA Centro de Diagnóstico em Saúde Animal

CIDASC Companhia Integrada de Desenvolvimento Agrícola de Santa Catarina

FMVZ Faculdade de Medicina Veterinária e Zootecnia

$\mathrm{H}_{0} \quad$ Hipótese nula

$\mathrm{H}_{1} \quad$ Hipótese alternativa

IBGE Instituto Brasileiro de Geografia e Estatística

IC Intervalo de confiança

MAPA Ministério da Agricultura, Pecuária e Abastecimento

$\mathrm{ml} \quad$ mililitro

$\mathrm{N}^{\circ} \quad$ Número

OIE Office International des Epizooties

PNCEBT Programa Nacional de Controle e Erradicação da Brucelose e Tuberculose

R Rank médio

SE $\quad$ Erro padrão

UI Unidade internacional

USP Universidade de São Paulo

VPS Departamento de Medicina Veterinária Preventiva e Saúde Animal 


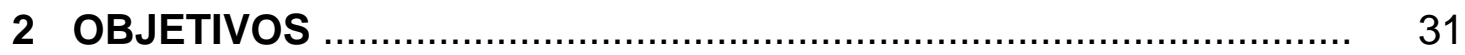

2.1 Objetivo geral .................................................................... 32

2.2 Objetivos específicos ………....................................................... 32

3 MATERIAL E MÉTODOS ….......................................................... 34

3.1 Planejamento amostral ....................................................... 35

3.2 Treinamento das equipes ……………….......................... 38

3.3 Realização do trabalho de campo …………............................... 40

3.3.1 Coleta e envio do material ......................................................... 40

3.3.1.1 Identificação da propriedade ........................................................ 40

3.3.1.2 Coleta de sangue ................................................................ 41

3.3.1.3 Preparo do soro ............................................................... 41

3.3.1.4 Identificação da amostra .......................................................... 42

3.3.1.5 Acondicionamento e estocagem ............................................... 42

3.3.1.6 Remessa de amostras .............................................................. 43

3.3.1.7 Fluxo do material .................................................................. 43

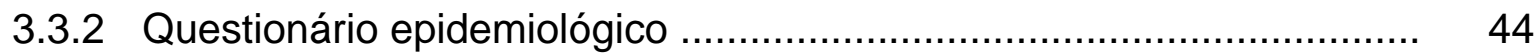

3.4 Testes diagnósticos …………............................................... 44

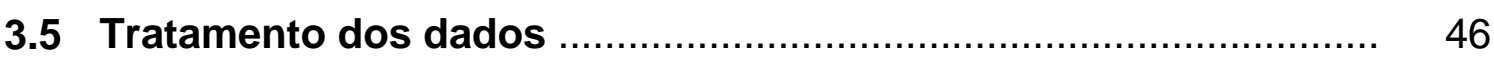

3.5.1 Cálculo das prevalências ............................................................ 47

3.5.1.1 Prevalência de focos de brucelose bovina no Estado de Santa 47 Catarina

3.5.1.2 Prevalência de animais soropositivos no Estado de Santa Catarina ... 48

3.5.2 Caracterização epidemiológica ....................................................... 49

3.5.2.1 Variáveis quantitativas ........................................................... 50

3.5.2.2 Variáveis qualitativas ................................................................... 53

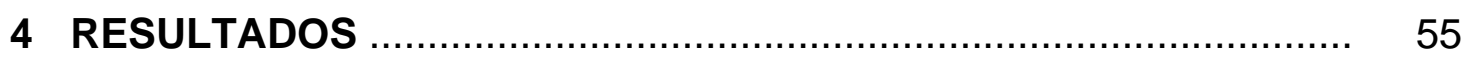

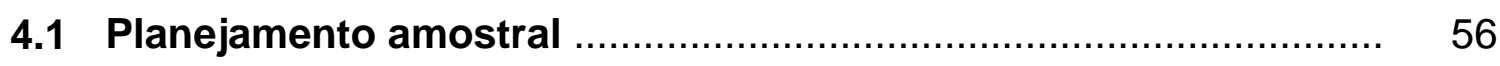

4.2 Prevalência de brucelose bovina no Estado de Santa Catarina .... 57

4.3 Caracterização epidemiológica ……………………………....... 59

4.3.1 Características gerais das propriedades ………………………......... 60

4.3.1.1 Tipo de exploração ...................................................................... 60

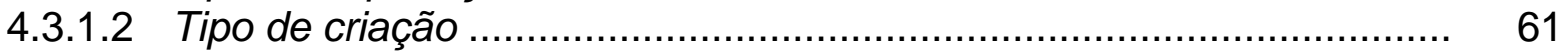

4.3.1.3 Número de bovinos ............................................................... 62 


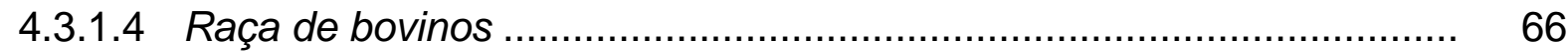

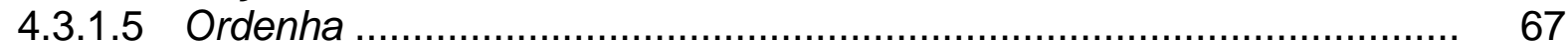

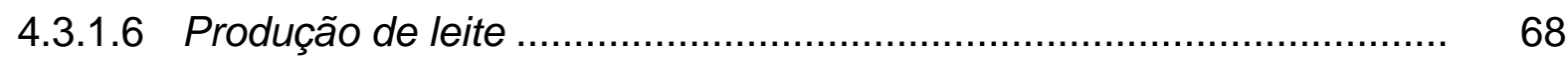

4.3.1.7 Resfriamento do leite ............................................................. 69

4.3.1.8 Inseminação artificial ................................................................ 70

4.3.2 Fatores de risco de brucelose em animais ...................................... 71

4.3.2.1 Outras espécies na propriedade ................................................. 71

4.3.2.2 Destino do aborto ................................................................. 73

4.3.2.3 Compra e venda de bovinos ....................................................... 74

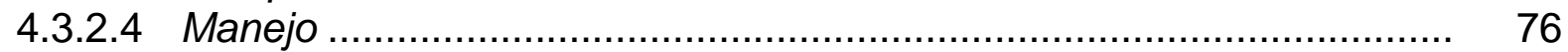

4.3.3 Fatores de risco de brucelose em humanos ................................... $\quad 76$

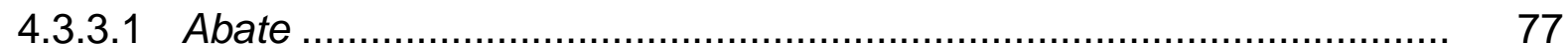

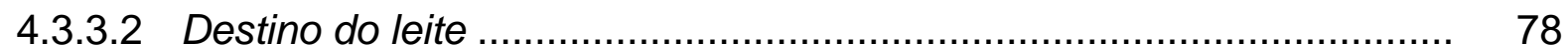

4.3.3.3 Produção de queijo e/ou manteiga ......................................................... 79

4.3.3.4 Consumo de leite cru ............................................................. 80

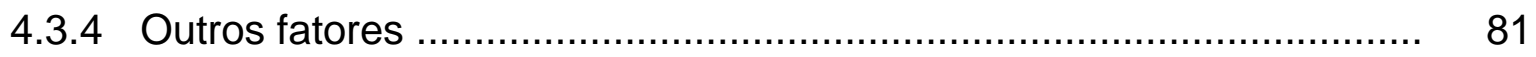

4.3.4.1 Testes para diagnóstico da brucelose …….................................... 81

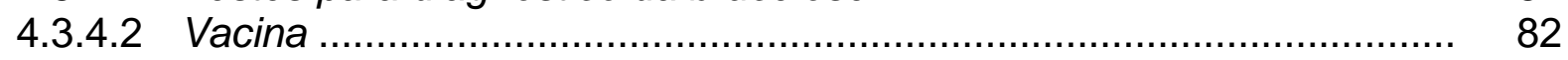

4.3.4.3 Assistência veterinária ................................................................. 83

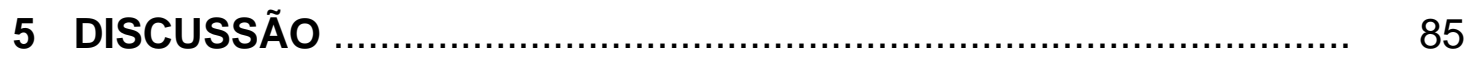

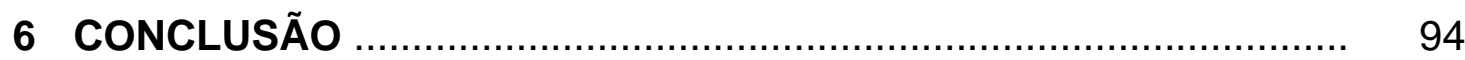

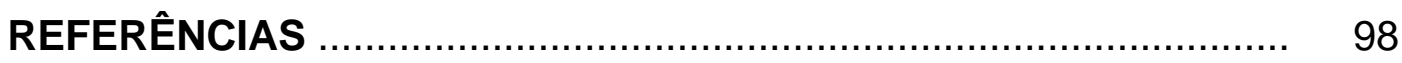

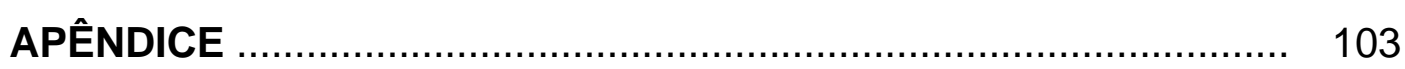

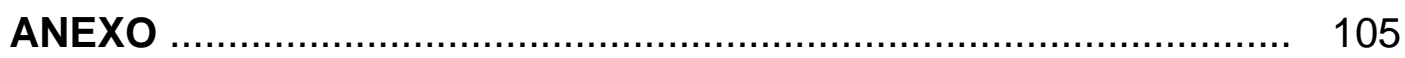




\section{Introdução}

"Nenhum homem poderá revelar-vos nada senão o que já está meio adormecido na aurora do vosso entendimento." (Kalil Gibran) 


\section{INTRODUÇÃO}

A brucelose bovina, causada pela Brucella abortus, é uma zoonose de evolução crônica, cujas manifestações nos animais contribuem para uma considerável baixa na produção de alimentos. No homem, a sua manifestação clínica é responsável por incapacidade parcial ou total para o trabalho (BRASIL, 2004).

É uma doença que faz parte da lista B de classificação de doenças da OIE (Office International des Epizooties), ou seja, é uma doença transmissível que possui importância sócio-econômica e/ou de saúde pública em países cujo comércio internacional de animais e de produtos de origem animal é significante (OIE, 2003).

A B. abortus está amplamente difundida pelo mundo, concentrando-se principalmente nos países subdesenvolvidos como África, América do Sul, Oriente Médio e Ásia (PAULIN; FERREIRA NETO, 2003).

O aborto no terço final da gestação é o sinal predominante nas fêmeas bovinas prenhes, assim como o nascimento prematuro ou mesmo o nascimento a termo de bezerros mortos ou enfraquecidos.

A fêmea bovina infectada e gestante (vaca ou novilha) tem o papel mais importante na difusão da brucelose, seja através do parto ou do aborto. A fêmea infectada não prenhe e em lactação pode difundir a doença através do leite, especialmente quando alimenta bezerros ou por contaminação dos equipamentos ou das instalações de ordenha (SÃO PAULO, 2002).

Touros são importantes na transmissão da doença, pois eliminam a bactéria no sêmen, o que não ocorre com novilhos e animais castrados (PAULIN; FERREIRA 
NETO, 2003). A inseminação artificial, a partir de touros infectados, constitui um mecanismo muito efetivo de transmissão da brucelose bovina a muitos rebanhos, já que nesse caso, o sêmen é depositado diretamente de forma intra-uterina (SÃO PAULO, 2002; VASCONCELLOS; ITO; CÔRTES, 1987). Já a possibilidade da transmissão da brucelose bovina pela monta natural é muito remota (VASCONCELLOS; ITO; CÔRTES, 1987) devido à ação das defesas naturais existentes na vagina, além de requerer uma elevada dose do agente (SÃO PAULO, 2002).

Os bezerros, novilhos e machos castrados infectados não são fonte de infecção direta para outros bovinos, mas têm importância na transmissão ao homem durante o abate em frigoríficos ou matadouros (SÃO PAULO, 2002).

Apesar do principal hospedeiro reservatório da $B$. abortus ser o bovino, outros animais domésticos também podem ser infectados e eventualmente transmitir a doença novamente ao bovino (SÃO PAULO, 2002).

Os eqüinos, embora sejam suscetíveis à $B$. abortus, são considerados elementos quase sempre terminais na cadeia de transmissão (LYRA, 1984; PAULIN; FERREIRA NETO, 2003; VASCONCELLOS; ITO; CÔRTES, 1987).

Os suínos são naturalmente acometidos pela Brucella suis, mas também são suscetíveis à infecção por B. abortus (VASCONCELLOS; ITO; CÔRTES, 1987). A infecção é transitória, podendo, por determinado período, servir de fonte de infecção para os bovinos (PAULIN; FERREIRA NETO, 2003). Embora seja raro, os bovinos também podem infectar-se pela $B$. suis, quando compartilham pastagens ou instalações com suínos infectados (SÃO PAULO, 2002).

No sistema de produção familiar, é comum a convivência no campo de bovinos e suínos. Os suínos podem estar infectados com a $B$. suis, resultando na 
possibilidade de que os bovinos sejam infectados por essa brucela (SÃO PAULO, 2002).

Os cães não são naturalmente afetados de forma grave pela infecção por $B$. abortus, mas podem adquirir a infecção e serem responsáveis pela disseminação do agente nas propriedades (LYRA, 1984), no sentido de carrearem produtos do aborto pelas pastagens e entre fazendas (VASCONCELLOS; ITO; CÔRTES, 1987).

Os contatos com rebanhos vizinhos e a existência de pastagens em comum são fatores que afetam de forma significativa a disseminação da infecção (NICOLETTI, 1998). A utilização de pastos em comum e a existência de rios ou charcos comuns permitem um maior contato entre os animais de outras propriedades e isso aumenta o risco (NICOLETTI, 1998; SALMAN; MEYER; HIRD, 1984).

É importante evitar que sejam produzidos partos e abortos no recinto de vacas leiteiras, assim como na área de novilhas e nas estâncias de pasto (BEER, 1988). Em torno de 12 e 18 meses depois de se realizar mudanças de manejo (consistindo em passar as vacas em final de gestação para piquetes de maternidade), os níveis de infecção são reduzidos em grandes rebanhos de leite (NICOLETTI, 1998).

Em termos gerais, quanto mais animais forem introduzidos no rebanho, maior o risco de introduzir animais infectados (CRAWFORD; HUBER; ADAMS, 1990), ou seja, a prevalência da infecção é maior nos rebanhos em que existe reposição do que naqueles em que o sistema de criação é fechado (NICOLETTI, 1998).

Os sistemas de produção familiar muitas vezes realimentam sua situação endêmica com a compra de vacas descartadas em rebanhos de cria ou leiteiros. $\mathrm{O}$ aborto, a infertilidade e a esterilidade são causas freqüentes que determinam a 
eliminação de vacas de muitos rebanhos. Os descartes aumentam a probabilidade de que se eliminem vacas infectadas, fato que aumenta o risco para outros rebanhos, particularmente quando o descarte ocorre sem controle sanitário. A compra é feita principalmente por antecedentes genéticos e produtivos do rebanho de origem, dando pouca importância geralmente ao aspecto sanitário quando não se têm programas específicos (SÃO PAULO, 2002).

Os reservatórios naturais, representados pelos ungulados silvestres, desempenham papel na epidemiologia da doença, pois atuam como mantenedores do agente no ambiente não modificado pelo homem (PAULIN; FERREIRA NETO, 2003).

No Brasil, foi realizado um estudo no Pantanal sul-matogrossense e a brucelose foi diagnosticada em duas queixadas, espécie silvestre comum nas Américas (ITO et al., 1998)

Há relatos em outros países de $B$. abortus e $B$. suis isolados de uma grande variedade de espécies silvestres, como por exemplo, bisões (Bison bison), alces (Cervus elaphus), javalis selvagens (Sus scrofa), lebres européias (Lepus capensis), raposas (Vulpes vulpes), búfalos africanos (Syncerus caffer) e renas (Rangifer tarandus), dentre outros. Existem também relatos de isolamento de cepas de brucela em vários mamíferos marinhos como focas, botos e golfinhos, porém essas cepas não pertencem às cepas já conhecidas (GODFROID, 2002).

Em programas de erradicação da brucelose bovina na União Européia e nos Estados Unidos foram dadas ênfase na identificação de possíveis reservatórios de B. abortus em animais silvestres. Numerosas amostras de ungulados selvagens, principalmente cervídeos, tiveram resultado positivo quando a brucelose era presente no gado. Em países onde os programas de erradicação têm obtido sucesso 
ou estão em estágio avançado e a erradicação está próxima de ser alcançada, são conhecidos poucos reservatórios de $B$. abortus em espécies silvestres, exceto o bisão e o alce na área do National Parks of the Greater Yellowstone (Estados Unidos) e no Wood Buffalo National Park (Canadá). Na África do Sul, o búfalo africano é considerado reservatório da B. abortus (GODFROID, 2002).

Antes da difusão do processo de pasteurização, a brucelose era transmitida ao homem principalmente pelo consumo de leite e derivados in natura e mais raramente pela ingestão de tecidos mal cozidos de animais doentes (GRASSO, 2000).

Muitas vacas infectadas eliminam a brucela pelo leite durante vários anos, sendo que a glândula não apresenta nenhuma alteração perceptível e o próprio leite possui aspecto normal (CORRÊA, 1975).

O consumo de queijo fresco não pasteurizado é muito comum no Brasil (POESTER; GONÇALVES; LAGE, 2002). A sobrevivência em queijos varia, segundo o tipo de queijo, entre 2 a 20 dias (LYRA, 1984).

O risco de contrair brucelose pela ingestão de carne bovina é extremamente baixo, pois normalmente as brucelas não são encontradas nos músculos desses animais e morrem quando submetidas a temperaturas utilizadas na culinária tradicional (MARTINS ${ }^{1}, 1994$ apud PAULIN; FERREIRA NETO, 2003, p. 28).

Após a instituição dos procedimentos de pasteurização do leite, a brucelose no homem passou a apresentar uma estreita relação com a atividade profissional, acometendo principalmente veterinários, trabalhadores de fazendas de criação, pessoal de matadouros e açougues (VASCONCELLOS; ITO; CÔRTES, 1987). Os indivíduos infectam-se através do contato com animais infectados (tecidos

\footnotetext{
${ }^{1}$ MARTINS, M. V. F. A. Brucella e os produtos alimentares de origem animal. Veterinária técnica, n.2, p. 20-23, 1994.
} 
infectados, produtos do abortamento, órgãos genitais dos animais infectados, excreções e secreções), através do leite não pasteurizado e seus subprodutos e em acidentes de laboratório. As portas de entrada mais comuns são mucosa oral e respiratória, conjuntiva ocular e pele lesada (CARTER; CHENGAPPA, 1991). Os sinais mais evidentes da brucelose no homem são os observados nos quadros de infecção generalizada aguda e ocorrem na fase de bacteremia: febre contínua e intermitente, respiração acelerada, calafrios e suores noturnos profusos, geralmente apresentando um odor particular (ACHA; SZYFRES, 1986). Na espécie humana, assim como em algumas outras espécies de animais, são raros os casos de brucelose antes da puberdade, sendo a maior freqüência de casos, em indivíduos com idade superior a 15 anos (VASCONCELLOS; ITO; CÔRTES, 1987).

Do ponto de vista epidemiológico, o homem representa um "ponto final" na propagação da doença. O caráter inter-humano na transmissão da brucelose, assim como a infecção do animal através do homem doente, apesar de teoricamente possível, é raro e contestável (LYRA, 1984).

Os prejuízos, que estão relacionadas à menor produtividade de leite e carne do rebanho acometido, ao menor valor dos animais e dos produtos provenientes de regiões infectadas, à perda de mercados potenciais e aos custos da doença humana decorrentes dos serviços médicos, diagnósticos, terapêuticos e afastamento da função produtiva (BENENSON, 1983; GARCIA-CARRILO, 1975; GARCIA-CARRILO, 1990; OIE, 1987; OMS, 1986; SAGDR ${ }^{2}, 1995$ apud GRASSO, 2000, p.91; SCHLÖGEL, 1966), são superiores aos custos dos programas organizados para o seu controle (ABDUSSALAM; FEIN, 1976; AMOSSON, 1984; OIE ${ }^{3}, 1987$ apud GRASSO, 2000, p.90). ${ }^{2}$ SECRETARIA DE AGRICULTURA GANADERIA Y DESARROLLO RURAL. Manual de actualizacion técnica para la aprobacion del medico veterinário em
tuberculosis bovina y brucelosis, $199599 \mathrm{p}$. 
Um exemplo disso é o Canadá, que estimou um ganho de 5 dólares para cada dólar investido durante 10 anos de programa (GARCIA-CARRILO, 1987).

Os rebanhos bovinos são desvalorizados não somente porque estão sujeitos a surtos de abortamento, como também a subsequentes distúrbios reprodutivos, com redução progressiva do rebanho pela queda da natalidade (GRASSO, 2000).

Estima-se que a brucelose bovina determina, entre outros: uma redução da produção leiteira de 20 a 25\%; uma perda da produção de carne de 10 a 15\%; uma perda de $15 \%$ dos bezerros ocasionadas por aborto, rompimento ou perda das linhas genéticas nos rebanhos infectados e conseqüente redução de seu valor comercial; uma, de cada cinco vacas que abortam torna-se estéril; as necessidades de reposição de animais em um rebanho infectado aumentam em aproximadamente $30 \%$ e o intervalo entre partos aumenta de 11,5 para 20 meses (FARIA, 1984).

Estudos realizados em fins dos anos 70 indicam que as perdas monetárias anuais ocasionadas pela brucelose representavam, em 11 países da América, incluindo-se o Brasil, cerca de 230 milhões de dólares (SÃO PAULO, 2002).

As estimativas de perda por brucelose bovina na América Latina giram em torno de 600 a 700 milhões de dólares anuais (FARIA, 1984). Em 1982, a Secretaria de Defesa Sanitária Animal do Brasil estimou que o país havia perdido, no mínimo, 30 milhões de dólares (OIE ${ }^{4}, 1987$ apud GRASSO, 2000, p.2).

Os prejuízos causados pela brucelose e o fato dela ser uma enfermidade que pode ser prevenida e erradicada, contribuem para a decisão tomada por vários países, alguns até há mais de duas décadas, de implementar programas para o seu controle, com êxitos consideráveis que têm levado à eliminação da brucelose em parte ou na totalidade dos seus territórios (SÃO PAULO, 2002).

\footnotetext{
${ }^{4}$ OFFICE INTERNATIONAL DES EPIZOOTIES. Brucelosis bovina, ovina y caprina. Série técnica n. 6, 1987, 282 p.
} 
Os programas contra a brucelose são preconizados desde 1896, mas foi a partir dos anos 30 que houve um incremento nas suas implantações. A importância do controle era explicada pela necessidade da preservação da saúde humana e redução de prejuízos econômicos (GRASSO, 2000).

A estruturação de um bom programa é fundamental. Um bom exemplo disso são os programas de países como Austrália, Canadá e Nova Zelândia, que atingiram a condição de erradicação (GRASSO, 2000).

A regionalização das ações faz com que os alvos das ações se aproximem dos responsáveis pelo planejamento e execução das mesmas, permitindo maior agilidade dos procedimentos. Apesar disso ser freqüente, principalmente nos países com grande território, a coordenação do governo central se mostra presente nos programas que obtiveram êxito, seja na gestão de recursos financeiros como na elaboração e fiscalização do cumprimento das metas estabelecidas (GARCIA-

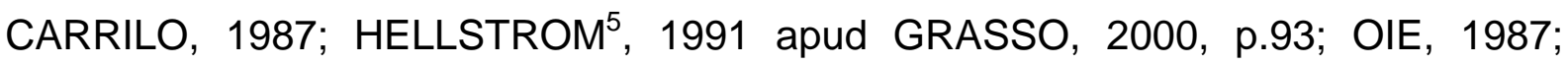
MacDIARMID, 1988; STEMSHORN, 1985).

Há quatro fases distintas no combate à brucelose bovina. A primeira fase é o rebaixamento da prevalência para valores inferiores a $2 \%$, o que se consegue ao atingir uma cobertura vacinal de $80 \%$ com a B19. A segunda fase é marcada fundamentalmente pelo abandono da vacinação e incremento das ações de diagnóstico e sacrifício sistemáticos dos animais reatores, num grande esforço de saneamento e certificação das unidades de criação como livres da doença. A terceira fase pode ser definida como de solução de problemas residuais, como por exemplo, a constatação da pouca eficiência do controle da movimentação de animais ou a participação importante de reservatórios na manutenção da infecção. A

\footnotetext{
${ }^{5}$ HELLSTROM, J. New Zealand is free from bovine brucellosis. Surveillance, v. 18, n. 1, p. 14, 1991.
} 
passagem da segunda para a terceira fase faz-se necessária quando se verifica a exaustão da estratégia de diagnóstico e sacrifício. Essa exaustão fica evidente quando se observa que a prevalência e a incidência da doença não baixam apesar dos esforços do programa. O aperfeiçoamento da estratégia, nesta fase, dependerá dos resultados dos estudos de individualização dos fatores de risco. A quarta fase é a de vigilância epidemiológica e consiste num conjunto de ações para impedir o retorno da infecção ou, caso reapareça, seja rapidamente detectada e eliminada por meio de medidas contingenciais (GRASSO, 2000).

No Brasil, o Ministério da Agricultura, Pecuária e Abastecimento (MAPA) criou, em 2001, o Programa Nacional de Controle e Erradicação da Brucelose e Tuberculose (PNCEBT) com o intuito de melhorar a eficácia de medidas de controle dessas duas doenças, a fim de promover a qualidade dos produtos de origem animal oferecidos ao consumidor e modernizar as cadeias produtivas do leite e da carne. Anteriormente, o controle da brucelose estava regulamentado pela portaria ministerial 23/76, mas as medidas não vinham atingindo a eficácia desejada, em razão da ausência de um programa estruturado que criasse estímulos para os pecuaristas adotarem ações sanitárias mais adequadas (BRASIL, 2001b).

Os objetivos específicos do PNCEBT são baixar a prevalência e a incidência de novos casos de brucelose e tuberculose e criar um número significativo de propriedades certificadas que ofereçam ao consumidor produtos de baixo risco sanitário.

A certificação de propriedades livres e de propriedades monitoradas, de adesão voluntária, é um instrumento que os produtores e o setor agro-industrial podem utilizar para agregar valor aos seus produtos. O PNCEBT envolve não apenas o governo federal e os governos estaduais, mas também o setor produtivo e 
suas comunidades, o setor industrial e os consumidores e os médicos veterinários que atuam no setor privado. O setor público atuará como agente certificador dentro de um processo que envolve diretamente toda a cadeia produtiva.

O PNCEBT é um programa importante não apenas para as cadeias produtivas de carne e leite, como também para os consumidores de produtos de origem animal e para a imagem que o país projeta nos mercados mundiais.

No Brasil, a brucelose bovina é endêmica em todo o território nacional e, apesar da sua prevalência e distribuição regional não estarem bem caracterizadas, sabe-se que existe heterogeneidade entre as regiões em relação à sua freqüência (PAULIN; FERREIRA NETO, 2002).

A brucelose bovina atinge tanto o gado de corte como o gado de leite, além de afetar também a população de bubalinos (BRASIL, 2001b). O controle constante da brucelose nos rebanhos leiteiros justifica-se pelo maior risco de transmissão da doença ao homem, seja por contato direto ou indireto, além da própria importância econômica da doença, relacionada à diminuição da produção de leite (LYRA, 1984).

O último diagnóstico de situação da brucelose bovina em nível nacional foi realizado em 1975, sendo que a estimativa da porcentagem de animais soropositivos foi de 4,0\% na região Sul; 7,5\% na região Sudeste; $6,8 \%$ na região Centro-Oeste; $2,5 \%$ na região Nordeste e $4,1 \%$ na região Norte. Posteriormente, outros estudos foram realizados nos Estados de Santa Catarina, Rio Grande do Sul, Paraná, Mato Grosso do Sul e Minas Gerais. Em Santa Catarina, a prevalência passou de 0,2\% em 1975 para 0,6\% em 1996 (BRASIL, 2001b).

Os dados de notificações oficiais indicam que a prevalência de animais soropositivos para brucelose se manteve entre 4\% e 5\% no período de 1988 a 1998 (BRASIL, 2004). 
A importância do conhecimento da situação epidemiológica da brucelose bovina no Estado de Santa Catarina é a de permitir a escolha das melhores estratégias para o controle e erradicação, pois estas podem diferir dependendo da freqüência e padrão de distribuição nas diferentes regiões e, conhecendo-se a situação atual, o acompanhamento do programa e o julgamento racional de correções, caso haja necessidade, seria facilitado.

Deve-se levar em conta que os custos relacionados aos procedimentos necessários para se atingir os objetivos do PNCEBT são altos. Conhecendo-se a situação epidemiológica das diferentes regiões, ações mais específicas e direcionadas seriam tomadas, agindo assim, de forma mais racional e diminuindo os custos.

O Departamento de Medicina Veterinária Preventiva e Saúde Animal da Faculdade de Medicina Veterinária e Zootecnia da Universidade de São Paulo (VPS - FMVZ / USP) fez uma parceria com o MAPA e os Serviços Estaduais de Defesa Sanitária Animal de 16 Unidades Federativas, entre elas, Santa Catarina, com o objetivo de realizar estudos que visem elucidar a situação epidemiológica da brucelose e tuberculose nos plantéis bovinos brasileiros para que se escolha as melhores condutas e estratégias para os vários Estados e regiões e criar mecanismos racionais de verificação da efetividade das ações implementadas.

Para o estudo da prevalência da brucelose bovina realizado em Santa Catarina foram escolhidas as fêmeas bovinas com idade igual ou superior a 12 meses porque são as fêmeas que desempenham o papel mais importante na difusão da brucelose, principalmente as gestantes e as que estão em fase de lactação. 


\section{Objetivos}

"Tudo que uma pessoa pode imaginar, outras podem tornar real."

(Júlio Verne) 


\section{OBJETIVOS}

O estudo da prevalência e caracterização epidemiológica da brucelose bovina no Estado de Santa Catarina tem como objetivos:

\subsection{Objetivo geral}

Estudar a situação epidemiológica da brucelose bovina no Estado de Santa Catarina.

\subsection{Objetivos específicos}

- Determinar a prevalência da brucelose bovina em fêmeas com idade igual ou superior a 12 meses no Estado de Santa Catarina;

- Identificar as diferenças de prevalência da brucelose bovina em fêmeas com idade igual ou superior a 12 meses nas cinco áreas em que foi subdividido o Estado de Santa Catarina;

- Caracterizar a tipologia das propriedades em cada uma das cinco áreas do Estado de Santa Catarina;

- Identificar semelhanças entre as áreas no que se refere às suas 
características epidemiológicas. 


\section{Material e métodos}

"Você não pode ensinar nada a um homem; você pode apenas ajudá-lo a encontrar a resposta dentro dele mesmo."

(Galileu Galilei) 


\section{MATERIAL E MÉTODOS}

Os materiais e métodos utilizados estão descritos a seguir.

\subsection{Planejamento amostral}

O Estado de Santa Catarina, com uma população de 2.556 .635 bovinos distribuídos em 168.909 propriedades (SANTA CATARINA, 2001), foi subdividido em cinco áreas epidemiológicas, seguindo os princípios que orientaram a criação dos circuitos pecuários do programa de controle da febre aftosa (Figura 1).

As cinco áreas abrangem as 16 administrações regionais (ADRs) da Companhia Integrada de Desenvolvimento Agrícola de Santa Catarina (CIDASC):

- Área 1: composta pela ADR de Lages, envolvendo uma população de 423.992 bovinos distribuídos em 13.024 propriedades, com 225.823 fêmeas com idade igual ou superior a 12 meses;

- Área 2: composta pelas ADRs de São José, Tubarão e Criciúma, envolvendo uma população de 338.325 bovinos distribuídos em 30.635 propriedades, com 163.609 fêmeas com idade igual ou superior a 12 meses;

- Área 3: composta pelas ADRs de Chapecó, Concórdia, Campos Novos, Caçador, Videira, Xanxerê e São Miguel do Oeste, envolvendo uma população de 1.280 .799 bovinos distribuídos em 80.754 propriedades, 
com 693.752 fêmeas com idade igual ou superior a 12 meses;

- Área 4: composta pela ADR de Mafra, envolvendo uma população de 155.402 bovinos distribuídos em 11.113 propriedades, com 86.319 fêmeas com idade igual ou superior a 12 meses;

- Área 5: composta pelas ADRs de Rio do Sul, Itajaí, Joinville e Blumenau, envolvendo uma população de 358.117 bovinos distribuídos em 33.383 propriedades, com 197.896 fêmeas com idade igual ou superior a 12 meses.

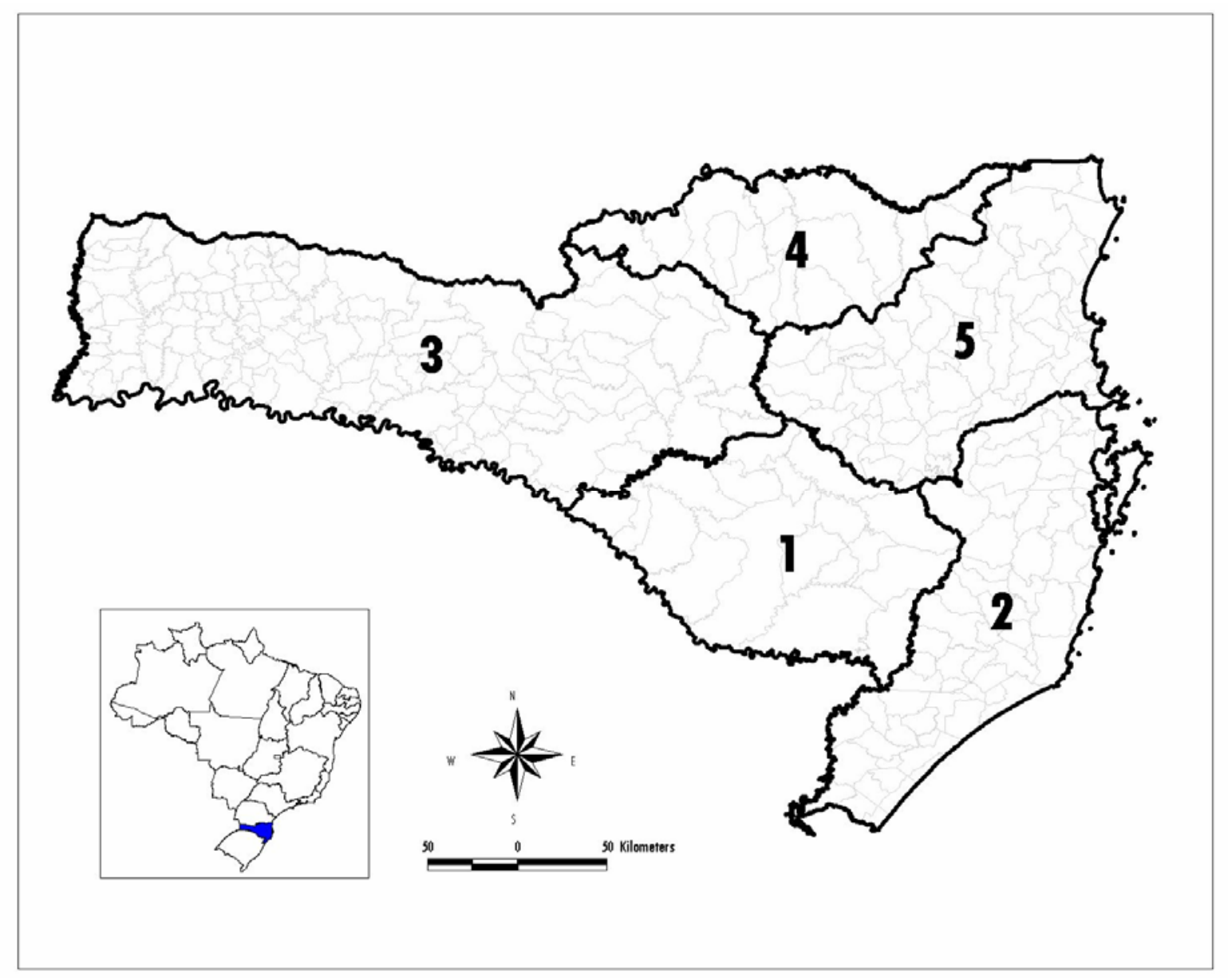

Figura 1 - Mapa do Estado de Santa Catarina demonstrando sua subdivisão em cinco áreas epidemiológicas 
Para cada área foi planejada uma amostra com o objetivo de se estimar a prevalência de focos e de animais soropositivos para brucelose. O planejamento amostral foi elaborado pelo MAPA.

Tais cálculos tiveram como orientação a combinação de boa capacidade discriminatória com operacionalidade.

O planejamento amostral foi realizado em duas etapas. Primeiramente sorteou-se, de forma aleatória, um número pré-estabelecido de unidades primárias de amostragem (propriedades). Posteriormente, foi investigado o estado sanitário do rebanho, através da escolha, também de forma aleatória, de um número préestabelecido de unidades secundárias (fêmeas com idade igual ou superior a 12 meses).

A técnica de amostragem utilizada para o sorteio das propriedades e dos animais foi a amostragem sistemática aleatória. O sorteio das propriedades foi realizado a partir de uma listagem das propriedades por município.

Nesse tipo de amostragem, são sorteadas $\mathrm{n}$ propriedades (ou animais) pertencentes a uma população composta de N propriedades (ou animais). Sorteia-se um número aleatório menor do que N/n e depois são selecionadas propriedades (ou animais) em intervalos regulares iguais a $\mathrm{N} / \mathrm{n}$.

A unidade amostral primária, representada por cada uma das propriedades amostradas, foi definida como sendo o agrupamento de bovinos em um rebanho sob os mesmos tipos de controle e manejo (mesma condição de risco).

Se fosse necessário substituir alguma propriedade sorteada inicialmente, a propriedade mais próxima e com as mesmas características de produção seria a escolhida.

A seleção aleatória de propriedades foi realizada com o objetivo de obter-se 
uma prevalência estimada com um intervalo de confiança de $95 \%$ e precisão de $5 \%$. O tamanho da amostra para estimar uma proporção é determinado pelo nível de confiança, pela precisão desejada e pelo valor de prevalência esperado ou mais provável.

O passo seguinte foi determinar o número de unidades amostrais secundárias (fêmeas bovinas com idade igual ou superior a 12 meses) em cada rebanho sorteado, ou seja, definir em quantos animais seriam realizados os testes diagnósticos de brucelose. Nesta etapa de amostragem, o objetivo era classificar o rebanho quanto à existência de animais sororeagentes.

Quando animais são testados individualmente para determinar o estado do rebanho, a validade do teste de diagnóstico, determinada por sua sensibilidade e especificidade, deve ser avaliada de forma agregada.

O número mínimo de animais a serem examinados para classificar as propriedades como foco ou livre foi calculado obedecendo a valores de sensibilidade agregada iguais ou superiores a 0,90 e especificidade agregada iguais ou superiores a 0,90. Para o procedimento diagnóstico da brucelose adotou-se como 0,95 e 0,995, respectivamente, os valores individuais de sensibilidade e especificidade.

Os cálculos foram realizados com o auxílio dos programas WinEpiscope 2.0 e Herdacc Input.

\subsection{Treinamento das equipes}

Os médicos veterinários (coordenadores de pecuária regional e responsáveis 
pelas equipes locais) foram treinados pela equipe central, com o objetivo de padronização de procedimentos para colheita de material junto aos municípios do Estado de Santa Catarina.

A equipe central é composta pelo gerente estadual e pelos médicos veterinários responsáveis pelos programas a nível central, no total de 3 equipes com o objetivo de fiscalizar "in loco" o andamento das equipes regionais e locais.

As equipes regionais são compostas pelos coordenadores regionais de pecuária, num total de 16 equipes, com o objetivo de fiscalizar "in loco" o trabalho executado pelas equipes locais.

As equipes locais são compostas pelos médicos veterinários da sub-área, num total de 83 equipes, com o objetivo de executar a coleta de material e preenchimento dos questionários nas propriedades. Cada equipe é formada por um médico veterinário e um auxiliar agropecuário.

O treinamento foi composto por um detalhamento do planejamento amostral para a área geográfica de atuação dos grupos e por treinamentos específicos para execução das colheitas de sangue e obtenção e remessa do soro para o laboratório e aplicação do questionário epidemiológico. O questionário epidemiológico foi planejado de maneira a permitir uma caracterização precisa da tipologia das propriedades foco.

Os participantes receberam material didático na forma de apostilas e vídeo.

Os responsáveis pelos laboratórios foram treinados em padronização das técnicas de laboratório em antígeno acidificado tamponado e 2-mercaptoetanol em São José, junto ao Laboratório de Sanidade Animal do Ministério da Agricultura convênio CIDASC.

Estas atividades foram realizadas em parceria com o MAPA e a CIDASC. 


\subsection{Realização do trabalho de campo}

As atividades de campo foram realizadas pela CIDASC no período de 1 a 30 de dezembro de 2001 e foram parcialmente financiadas pelo Governo Federal, na forma de repasses para o Estado de Santa Catarina, que por sua vez se encarregaram dos custos com pessoal, deslocamentos e testes diagnósticos.

\subsubsection{Coleta e envio do material}

O sangue dos animais foi coletado nas propriedades selecionadas, em fêmeas bovinas com idade igual ou superior a 12 meses conforme as áreas amostradas.

O sangue foi coletado em tubo de vacutainer (sem anticoagulante), dessorado em tubo de penicilina no escritório local, etiquetados, congelados, acondicionados e enviados aos laboratórios regionais da CIDASC, segundo o manual de procedimentos (BRASIL, 2001a; SANTA CATARINA, 2001):

\subsubsection{Identificação da propriedade}


A identificação da propriedade foi feita no formulário específico:

- Campo1: município em que foi realizada a sorologia, nome do proprietário, da propriedade e código do proprietário, de acordo com a ficha do criador;

- Campo 2: data da visita e da coleta;

- Campo 3: código do rebanho no estudo (9 dígitos). Este código é feito adotando-se o seguinte critério: código do IBGE (7 dígitos) + número seqüencial da propriedade sorteada (2 dígitos);

- Campo 32: número do frasco (11 dígitos). Esse campo é preenchido adotando-se o seguinte critério: código do campo 3 (9 dígitos) + seqüência do número de fêmeas amostradas (2 dígitos).

\subsubsection{Coleta de sangue}

A sangria foi realizada em tubos vacutainer de capacidade $15 \mathrm{ml}$, com agulha de coleta individualizada, num volume de sangue de $9 \mathrm{ml}$ no máximo, o que corresponde a $60 \%$ da capacidade do tubo, visando melhor obtenção do soro.

\subsubsection{Preparo do soro}

O tubo foi inclinado num ângulo aproximado de $45^{\circ}$, à temperatura ambiente, 
durante o tempo necessário para dessorar.

Após o dessoramento, o soro foi transferido cuidadosamente para os frascos de penicilina numa quantidade mínima de $3 \mathrm{ml}$ e máxima correspondente ao volume de $50 \%$ de capacidade do frasco, evitando assim, problemas no congelamento.

No caso de haver dificuldades na separação do coágulo, este poderia ser retalhado com estilete de madeira individualizado e descartável.

\subsubsection{Identificação da amostra}

Os frascos de penicilina com soro foram identificados com o número seqüencial informado no formulário específico contendo 11 dígitos (conforme informação do item 3.3.1.1) em rótulo de esparadrapo com caneta esferográfica.

\subsubsection{Acondicionamento e estocagem}

Para fixar a tampa, utilizou-se esparadrapo ou fita gomada na boca do frasco.

Os frascos foram congelados na posição vertical, acondicionados em sacos plásticos.

Foram tomados os devidos cuidados para que os frascos não virassem durante o transporte. 


\subsubsection{Remessa de amostras}

O transporte da amostra foi realizado em caixas de isopor, com gelo, preenchendo espaços vazios com jornal.

A primeira via do formulário, destinada ao laboratório, foi envolta em plástico, fixada à frente externa da tampa, com fita adesiva onde constava claramente o destinatário.

\subsubsection{Fluxo do material}

As amostras foram enviadas para os laboratórios de acordo com o Quadro 1.

\begin{tabular}{|c|c|}
\hline ADR & Laboratório \\
\hline Concórdia & Concórdia (CEDISA) \\
\hline Mafra & Mafra \\
\hline Lages & Lages \\
\hline Tubarão & \multirow{2}{*}{ Joinville } \\
\hline Joinville & \\
\hline Chapecó & \multirow{3}{*}{ Chapecó } \\
\hline Xanxerê & \\
\hline São Miguel do Oeste & \\
\hline Campos Novos & \multirow{3}{*}{ Joaçaba } \\
\hline Videira & \\
\hline Caçador & \\
\hline Rio do Sul & \multirow{2}{*}{ Rio do Sul } \\
\hline São José & \\
\hline Itajaí & \multirow{3}{*}{ Blumenau } \\
\hline Blumenau & \\
\hline Criciúma & \\
\hline Estado & \\
\hline
\end{tabular}




\subsubsection{Questionário epidemiológico}

Juntamente com o material coletado foi preenchido um questionário educativo epidemiológico (Anexo) em duas vias, sendo que a primeira via acompanhou o soro ao laboratório, envolta em plástico, fixada à frente externa da tampa com fita adesiva, onde constava o destinatário e a segunda permaneceu nos arquivos locais.

\subsection{Testes diagnósticos}

Foram adotados dois testes em série, a soroaglutinação com antígeno acidificado tamponado para a triagem e a prova do 2-mercaptoetanol como confirmatória.

O teste de soroaglutinação com antígeno acidificado tamponado (AAT) é um teste qualitativo rápido, prático e de boa sensibilidade e é considerado uma das melhores alternativas para o diagnóstico em massa de rebanhos (PAULIN; FERREIRA NETO, 2003). A maioria dos soros de animais bacteriologicamente positivos apresenta reação a essa prova. Como pode ocorrer alguns poucos casos de reações falso-positivas em decorrência da utilização da vacina B19, é importante que toda reação positiva nesse teste seja confirmada por testes de maior especificidade. É uma prova qualitativa, pois não indica o título de anticorpos do soro 
testado. A leitura revela a presença ou ausência de IgG1. Nas provas clássicas de aglutinação, reagem tanto anticorpos $\lg M$ como $\lg G$, enquanto que nessa prova, reagem somente os isotipos da classe IgG1. O pH acidificado da mistura soroantígeno inibe a aglutinação do antígeno pelas IgM. Esse teste detecta com maior precocidade as infecções recentes, mais do que a prova lenta em tubos (BRASIL, 2004).

A interpretação dos resultados é realizada de acordo com os seguintes critérios (BRASIL, 2004):

- Presença de grumos: reagente;

- Ausência de grumos: não reagente.

O teste do 2-mercaptoetanol (2-ME) é um teste de aglutinação que tem sua especificidade aumentada por um processo químico, que consiste no tratamento do soro com o mercaptoetanol. Isso impede a ocorrência da maioria das reações inespecíficas (PAULIN; FERREIRA NETO, 2003).

É uma prova quantitativa seletiva que detecta somente a presença de $\lg G$ no soro, que é a imunoglobulina indicativa de infecção crônica. Baseia-se no fato dos anticorpos da classe IgM, com configuração pentamérica, degradarem-se em subunidades pela ação de compostos que contenham radicais tiol. Essas subunidades não dão origem a complexos suficientemente grandes para provocar aglutinação. Desse modo, soros com predomínio de IgM apresentam reações negativas nessa prova e reações positivas na prova lenta (BRASIL, 2004).

A interpretação dos resultados é feita de acordo com as Tabelas 1 e 2 (BRASIL, 2001b) e é dada pela diferença entre os títulos dos soros sem tratamento (prova lenta), frente ao soro tratado com 2-ME. Os resultados positivos na prova lenta e negativos no 2-ME devem ser interpretados como reações inespecíficas ou 
como devidos a anticorpos residuais de vacinação com B19. Resultados positivos em ambas as provas indicam a presença de IgG, que são as aglutininas relacionadas com infecção, devendo os animais ser considerados infectados (BRASIL, 2004).

Tabela 1 - Interpretação do teste do 2-ME para fêmeas com idade igual ou superior a 24 meses, vacinadas entre 3 e 8 meses de idade

\begin{tabular}{ccl}
\hline Soroaglutinação lenta $(\mathrm{Ul} / \mathrm{ml})$ & 2-ME $(\mathrm{Ul} / \mathrm{ml})$ & Interpretação \\
\hline$\leq 50$ & $<25$ & Negativo \\
$\geq 100$ & $<25$ & Inconclusivo \\
$\geq 25$ & $\geq 25$ & Positivo \\
\hline
\end{tabular}

UI - Unidade Internacional

Fonte: BRASIL, 2001b

Tabela 2 - Interpretação do teste do 2-ME para fêmeas não vacinadas e machos, com idade superior a 8 meses

\begin{tabular}{ccl}
\hline Soroaglutinação lenta $(\mathrm{Ul} / \mathrm{ml})$ & 2-ME $(\mathrm{Ul} / \mathrm{ml})$ & Interpretação \\
\hline$\leq 25$ & $<25$ & Negativo \\
$\geq 50$ & $<25$ & Inconclusivo \\
$\geq 25$ & $\geq 25$ & Positivo \\
\hline
\end{tabular}

UI - Unidade Internacional

Fonte: BRASIL, 2001b

Os testes de triagem foram realizados nos laboratórios citados no Quadro 1 e os testes confirmatórios foram realizados no laboratório de referência (Centro de Diagnóstico em Saúde Animal - CEDISA), localizado em Concórdia.

\subsection{Tratamento dos dados}

Foi calculada a prevalência da brucelose bovina em fêmeas com idade igual 
ou superior a 12 meses e, através dos dados obtidos com a aplicação do questionário, foi realizada a caracterização epidemiológica do Estado de Santa Catarina.

\subsubsection{Cálculo das prevalências}

As prevalências de focos e de animais soropositivos no Estado de Santa Catarina foram calculadas com o auxílio dos programas SPSS e EPI INFO.

\subsubsection{Prevalência de focos de brucelose bovina no Estado de Santa Catarina}

Para o cálculo da prevalência de focos de brucelose bovina no Estado de Santa Catarina, considerou-se a amostra aleatória estratificada como desenho amostral.

Cada uma das cinco áreas em que foi subdividido o Estado de Santa Catarina foi considerada como sendo um estrato.

Os parâmetros necessários para o cálculo foram o resultado da propriedade (positivo ou negativo), a área a qual a propriedade pertencia e o peso estatístico, que é calculado da seguinte forma:

$$
\text { Peso estatístico }=\frac{n^{\circ} \text { total de propriedades na área }}{n^{\circ} \text { de propriedades amostradas na área }}
$$


Considerou-se a amostra aleatória simples como desenho amostral para o cálculo da prevalência de focos de brucelose bovina em cada uma das cinco áreas do Estado de Santa Catarina.

Os parâmetros necessários para o cálculo foram o número de focos e o número de propriedades amostradas na área.

Foi considerado foco a propriedade que tinha pelo menos um animal soropositivo para brucelose.

\subsubsection{Prevalência de animais soropositivos no Estado de Santa Catarina}

No cálculo da prevalência de animais soropositivos no Estado de Santa Catarina, considerou-se a amostra estratificada e por cluster como sendo o desenho amostral. No cálculo da prevalência de animais soropositivos em cada uma das cinco áreas o desenho amostral considerado foi a amostragem por cluster.

Cada uma das cinco áreas em que foi subdividido o Estado de Santa Catarina foi considerada como sendo um estrato e cada propriedade foi considerada como sendo um cluster.

$\mathrm{Na}$ amostragem por cluster em dois estágios, uma amostra de clusters é selecionada, seguida de uma subamostragem de alguns animais dos clusters. Os clusters são as unidades primárias e os animais selecionados nas subamostras são as unidades secundárias (THRUSFIELD, 1995). 
Os parâmetros utilizados foram o resultado final (animal positivo ou negativo), a área a qual o animal pertencia, o código do rebanho e o peso estatístico de cada animal, que é calculado da seguinte forma:

Peso estatístico = fração $A \times$ fração $B$

Fração $A=\frac{n^{\circ} \text { total fêmeas } \geq 12 \text { meses na área }}{n^{\circ} \text { total fêmeas } \geq 12 \text { meses nas propriedades amostradas na área }}$

Fração $B=\frac{n^{\circ} \text { total fêmeas } \geq 12 \text { meses na propriedade }}{n^{\circ} \text { fêmeas } \geq 12 \text { meses amostradas na propriedade }}$

A fração $A$ fornece o número de animais que cada animal potencialmente selecionado em uma propriedade representa na população.

A fração B fornece o número de animais que cada animal potencialmente selecionado representa na propriedade.

\subsubsection{Caracterização epidemiológica}

A caracterização epidemiológica das cinco áreas em que foi subdividido o Estado de Santa Catarina é importante para que o planejamento das ações respeite as peculiaridades de cada uma dessas áreas. Através da caracterização epidemiológica também é possível verificar a existência de possíveis semelhanças entre duas ou mais áreas e, caso isso ocorra, a união das mesmas facilitaria as medidas de controle e erradicação, não apenas da brucelose, como também de 
outras doenças.

Para a caracterização epidemiológica foram utilizados os dados obtidos com a aplicação do questionário nas propriedades.

\subsubsection{Variáveis quantitativas}

As variáveis quantitativas utilizadas no estudo da caracterização epidemiológica das áreas do Estado de Santa Catarina estão listadas no Quadro 2.

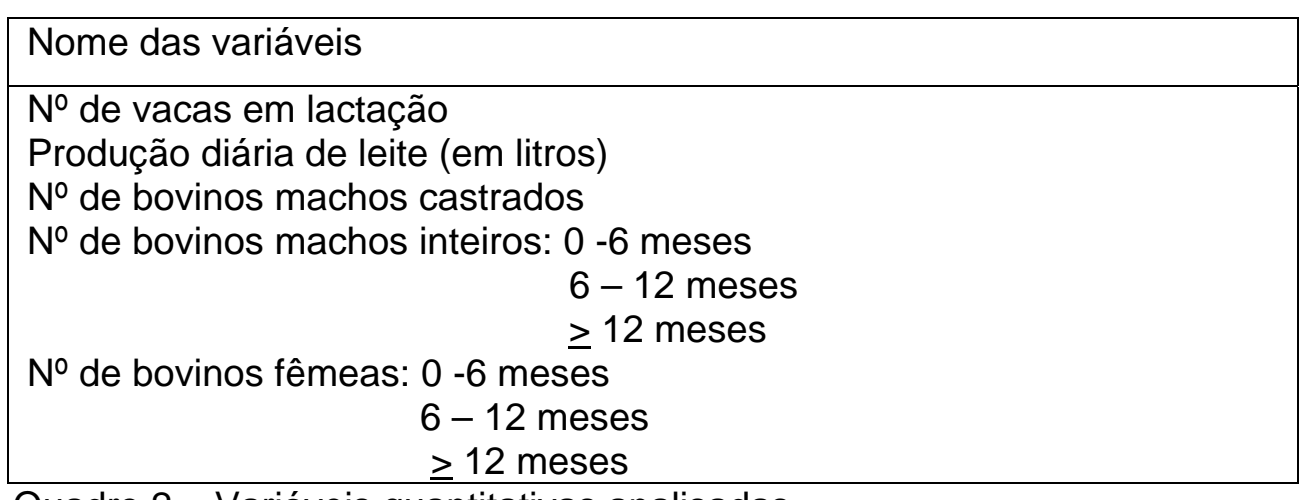

Quadro 2 - Variáveis quantitativas analisadas

Além dessas variáveis, trabalhou-se também com outras variáveis derivadas dessas, como a produção diária de leite por fêmeas em lactação e a proporção de bovinos de acordo com o sexo e a faixa etária.

Foi realizada uma análise estatística descritiva, ou seja, foram calculados a média, o erro padrão da média, o intervalo de confiança da média, a mediana, a variância, o desvio padrão, o mínimo, o máximo e os quartis de cada uma das variáveis em cada área. Esses cálculos foram feitos com o auxilio dos programas MINITAB e SPSS. 
O passo seguinte foi verificar se a distribuição das variáveis é semelhante nas cinco áreas. Trata-se, portanto, de uma comparação de k grupos, sendo k=5, já que vão ser comparadas as médias ou medianas das variáveis das cinco áreas.

Em primeiro lugar, deve-se verificar se as variáveis quantitativas apresentam distribuição normal. Para isso, realiza-se o seguinte teste de hipóteses:

$\mathrm{H}_{0}$ : os dados referentes à variável apresentam distribuição normal.

$\mathrm{H}_{1}$ : os dados referentes à variável não apresentam distribuição normal.

Como as variáveis possuem dados que não se comportam como distribuição normal, o teste estatístico escolhido foi um teste não-paramétrico denominado teste de Kruskal-Wallis.

O teste de Kruskal-Wallis é utilizado para decidir se as diferenças entre as amostras significam diferenças efetivas entre as populações ou se representam apenas variações casuais, que podem ser esperadas entre amostras aleatórias de uma mesma população (SIEGEL, 1975).

O teste de hipóteses elaborado é o seguinte:

$\mathrm{H}_{0}$ : as medianas das variáveis são estatisticamente iguais nas cinco áreas.

$\mathrm{H}_{1}$ : as medianas das variáveis são estatisticamente diferentes nas cinco áreas.

Os testes foram realizados com o auxilio do programa MINITAB.

Como o teste de Kruskal-Wallis nos fornece como resultado apenas se há diferença ou não entre as amostras e não fornece quais amostras são diferentes 
entre si, o próximo passo é fazer um teste não-paramétrico de comparação múltipla.

O teste utilizado foi proposto por Dunn (ZAR, 1996). As comparações são feitas duas a duas.

Em primeiro lugar deve-se elaborar um teste de hipóteses, onde:

$\mathrm{H}_{0}$ : as medianas das variáveis são estatisticamente iguais nas duas áreas.

$\mathrm{H}_{1}$ : as medianas das variáveis são estatisticamente diferentes nas duas áreas.

A estatística $(Q)$ é calculada da seguinte maneira:

$Q=\frac{R_{2}-R_{1}}{S E}$

onde: $R=$ rank médio (calculado no teste de Kruskal-Wallis).

SE = erro padrão

O erro padrão (SE) é calculado da seguinte forma:

$S E=\sqrt{\frac{N(N+1)}{12}\left(\frac{1}{n_{1}}+\frac{1}{n_{2}}\right)}$

onde: $N=n_{1}+n_{2}+n_{3}+n_{4}+n_{5}$

$n_{1}=$ tamanho da amostra na área 1

$n_{2}=$ tamanho da amostra na área 2 
Tanto o erro padrão (SE) como o valor de $Q$ devem ser calculados para cada uma das comparações, portanto, quando se comparam as áreas 1 e 2, utilizam-se $n_{1}$ e $\mathrm{n}_{2}$ (para o cálculo do $S E$ ) e $\mathrm{R}_{1}$ e $\mathrm{R}_{2}$ (para o cálculo de $Q$ ); quando se comparam as áreas 1 e 3, utilizam-se $n_{1}$ e $n_{3}$ e $R_{1}$ e $R_{3}$ e assim sucessivamente.

Para decidir se as áreas são iguais ou diferentes em relação a cada variável, basta comparar o valor de $Q$ com o valor crítico $Q_{\alpha ; k}$ onde $\alpha=0,05$ e k=5:

- se $Q>Q_{0,05 ; 5}$ rejeita-se $H_{0}$;

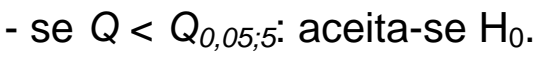

O valor de $Q_{0,05 ; 5}$ é obtido através de tabela (ZAR, 1996).

\subsubsection{Variáveis qualitativas}

As variáveis qualitativas utilizadas no estudo da caracterização epidemiológica das áreas do Estado de Santa Catarina estão listadas no Quadro 3. Foram calculados a freqüência e o intervalo de confiança. Na seqüência, procurouse verificar se havia homogeneidade das áreas através do teste do qui-quadrado. O nível de significância utilizado foi de 5\%.

Os cálculos foram feitos com o auxilio dos programas SPSS, EPI INFO e STATXACT. 


\begin{tabular}{|l|}
\hline Nome das variáveis \\
\hline Tipo de exploração \\
Tipo de criação \\
No de ordenhas por dia (3 categorias) \\
Tipo de ordenha \\
Uso de inseminação artificial \\
Raça de bovino predominante \\
Outras espécies na propriedade \\
Espécies silvestres em vida livre na propriedade \\
Aborto de vaca nos últimos 12 meses \\
Destino do feto abortado e da placenta \\
Realização de testes para diagnóstico de brucelose \\
Regularidade dos testes para diagnóstico de brucelose \\
Compra de fêmeas ou machos com finalidade de reprodução \\
Venda de fêmeas ou machos para reprodução \\
Vacina contra a brucelose \\
Local de abate de fêmeas e machos adultos no fim da vida reprodutiva \\
Aluguel de pastos em alguma época do ano \\
Existência de pastos em comum com outras propriedades \\
Áreas alagadiças na propriedade às quais o gado tem acesso \\
Piquetes separados para fêmeas na fase de parto e/ou pós-parto \\
Destino do leite \\
Resfriamento do leite \\
Entrega de leite a granel \\
Produção de queijo e/ou manteiga na propriedade \\
Consumo de leite cru \\
Assistência veterinária
\end{tabular}

Quadro 3 - Variáveis qualitativas analisadas 


\section{Resultados}

"A adversidade desperta em nós capacidades que, em circunstâncias favoráveis, teriam ficado adormecidas."

(Horácio) 


\section{RESULTADOS}

Os resultados do presente estudo se encontram descritos a seguir.

\subsection{Planejamento amostral}

O tamanho da amostra coletada no Estado de Santa Catarina foi de 1.600 propriedades, com coleta de soro em até 10 fêmeas com idade igual ou superior a 12 meses em cada propriedade, de acordo com a Tabela 3. No caso de haver menos de 10 fêmeas com essa faixa etária, a indicação foi de sangrar somente estas e no caso de haver mais de 10 fêmeas, a indicação foi de se fazer um sorteio na propriedade. 
Tabela 3 - Número total e amostrado de propriedades e de fêmeas bovinas com idade igual ou superior a 12 meses no Estado de Santa Catarina segundo a área

\begin{tabular}{|c|c|c|c|c|c|c|c|}
\hline \multicolumn{3}{|c|}{ ESTADO DE SANTA CATARINA } & \multicolumn{3}{|c|}{ REBANHO BOVINO } & \multicolumn{2}{|c|}{ AMOSTRAGEM } \\
\hline Área & ADR & $\begin{array}{c}\mathrm{N}^{\circ} \\
\text { municípios }\end{array}$ & $\begin{array}{c}\mathrm{N}^{\circ} \\
\text { propriedades }\end{array}$ & $\begin{array}{c}\mathrm{N}^{\circ} \\
\text { bovinos }\end{array}$ & $\begin{array}{l}N^{\circ} \text { fêmeas } \\
\geq 12 \text { meses }\end{array}$ & $\begin{array}{c}\mathrm{N}^{\circ} \\
\text { proprieda } \\
\text { des } \\
\end{array}$ & $\begin{array}{c}N^{\circ} \text { fêmeas } \\
\geq 12 \\
\text { meses }\end{array}$ \\
\hline \multirow{2}{*}{1} & Lages & 19 & 13.024 & 423.992 & 225.823 & 300 & 3.000 \\
\hline & Soma & 19 & 13.024 & 423.992 & 225.823 & 300 & 3.000 \\
\hline \multirow{4}{*}{2} & São José & 22 & 8.744 & 104.963 & 51.152 & 86 & 860 \\
\hline & Tubarão & 18 & 11.780 & 134.119 & 65.093 & 115 & 1.150 \\
\hline & Criciúma & 25 & 10.111 & 99.243 & 47.364 & 99 & 990 \\
\hline & Soma & 65 & 30.635 & 338.325 & 163.609 & 300 & 3.000 \\
\hline \multirow{8}{*}{3} & Chapecó & 38 & $24 . .658$ & 322.566 & 169.791 & 122 & 1.220 \\
\hline & Concórdia & 16 & 11.931 & 168.844 & 96.862 & 59 & 590 \\
\hline & Campos Novos & 18 & 8.109 & 199.170 & 106.947 & 40 & 400 \\
\hline & Caçador & 11 & 4.451 & 125.411 & 69.990 & 22 & 220 \\
\hline & Videira & 09 & 3.457 & 47.432 & 26.933 & 17 & 170 \\
\hline & Xanxerê & 17 & 9.590 & 161.858 & 89.043 & 48 & 480 \\
\hline & S. Miguel Oeste & 21 & 18.558 & 255.474 & 134.186 & 92 & 920 \\
\hline & Soma & 130 & 80.754 & 1.280 .799 & 693.752 & 400 & 4.000 \\
\hline \multirow{2}{*}{4} & Mafra & 14 & 11.113 & 155.402 & 86.319 & 300 & 3.000 \\
\hline & Soma & 14 & 11.113 & 155.402 & 86.319 & 300 & 3.000 \\
\hline \multirow{5}{*}{5} & Rio do Sul & 27 & 15.975 & 172.730 & 103.705 & 144 & 1.440 \\
\hline & Itajaí & 14 & 3.692 & 53.313 & 22.929 & 33 & 330 \\
\hline & Joinville & 13 & 5.080 & 60.367 & 30.494 & 46 & 460 \\
\hline & Blumenau & 11 & 8.636 & 71.707 & 40.768 & 77 & 770 \\
\hline & Soma & 65 & 33.383 & 358.117 & 197.896 & 300 & 3.000 \\
\hline Total & Santa Catarina & 293 & 168.909 & 2.556 .635 & 1.367 .399 & 1.600 & 16.000 \\
\hline
\end{tabular}

\subsection{Prevalência de brucelose bovina no Estado de Santa Catarina}

As prevalências de focos e de animais soropositivos para brucelose no

Estado de Santa Catarina estão apresentadas nas Tabelas 4 e 5, respectivamente. 
Tabela 4 - Prevalência de focos de brucelose bovina - Santa Catarina, 2001

\begin{tabular}{ccccccc}
\hline Área & $\begin{array}{c}\mathbf{N}^{\mathbf{0}} \text { total } \\
\text { propriedades }\end{array}$ & $\begin{array}{c}\mathbf{N}^{\mathbf{0}} \\
\text { propriedades } \\
\text { amostradas }\end{array}$ & $\begin{array}{c}\mathbf{N}^{\mathbf{0}} \\
\text { propriedades } \\
\text { positivas }\end{array}$ & $\begin{array}{c}\text { Prevalência } \\
\text { focos(\%) }\end{array}$ & IC 95\% (\%) ${ }^{(\mathbf{1})}$ & $\begin{array}{c}\text { Efeito } \\
\text { desenho }\end{array}$ \\
\hline $\mathbf{1}$ & 13.024 & 299 & 0 & 0,00 & ${ }^{(2)}[0,00-0,00]$ & - \\
$\mathbf{2}$ & 30.635 & 297 & 0 & 0,00 & ${ }^{(3)}[0,00-0,00]$ & - \\
$\mathbf{3}$ & 80.754 & 396 & 0 & 0,00 & ${ }^{(4)}[0,00-0,00]$ & - \\
$\mathbf{4}$ & 11.113 & 297 & 1 & 0,34 & ${ }^{(5)}[0,05-2,30]$ & 0,35 \\
$\mathbf{5}$ & 33.383 & 290 & 0 & 0,00 & ${ }^{(6)}[0,00-0,00]$ & - \\
\hline Total & $\mathbf{1 6 8 . 9 0 9}$ & $\mathbf{1 . 5 7 9}$ & $\mathbf{1}$ & $\mathbf{0 , 0 2}$ & {$[\mathbf{0 , 0 0 - 0 , 1 5 ]}$} & $\mathbf{0 , 3 4}$ \\
\hline
\end{tabular}

(1) IC calculado pelo SPSS

(2) IC calculado pelo EPITABLE: IC 95\% (binomial exata): [0,00-1,23\%]

(3) IC calculado pelo EPITABLE: IC 95\% (binomial exata): [0,00-1,23\%]

(4) IC calculado pelo EPITABLE: IC 95\% (binomial exata): [0,00-0,93\%]

(5) IC calculado pelo EPITABLE: IC 95\% (binomial exata): [0,00-1,86\%]

(6) IC calculado pelo EPITABLE: IC 95\% (binomial exata): [0,00-1,26\%]

Tabela 5 - Prevalência de animais soropositivos para brucelose - Santa Catarina, 2001

\begin{tabular}{cccccccc}
\hline Área & $\begin{array}{c}\mathbf{N}^{\mathbf{0}} \text { total } \\
\text { fêmeas } \\
\mathbf{2} \mathbf{1 2 m e s e s}\end{array}$ & $\begin{array}{c}\mathbf{N}^{\mathbf{0}} \text { fêmeas } \\
\mathbf{2} \mathbf{1 2 m e s e s} \\
\text { propriedades } \\
\text { amostradas }\end{array}$ & $\begin{array}{c}\mathbf{N}^{\mathbf{0}} \text { soros } \\
\text { amostra } \\
\text { dos }\end{array}$ & $\begin{array}{c}\mathbf{N}^{\mathbf{0}} \\
\text { animais } \\
\text { soroposi } \\
\text { tivos }\end{array}$ & $\begin{array}{c}\text { Prevalência } \\
\text { animais } \\
\text { soropositivos } \\
\mathbf{( \% )}\end{array}$ & IC 95\% (\%) & $\begin{array}{c}\text { Efeito } \\
\text { desenho }\end{array}$ \\
\hline $\mathbf{1}$ & 225.823 & 7.233 & 1.920 & 0 & 0,00 & {$[0,00-0,00]$} & - \\
$\mathbf{2}$ & 163.609 & 2.029 & 1.243 & 0 & 0,00 & {$[0,00-0,00]$} & - \\
$\mathbf{3}$ & 693.752 & 4.511 & 2.171 & 0 & 0,00 & {$[0,00-0,00]$} & - \\
$\mathbf{4}$ & 86.319 & 2.204 & 1.174 & 2 & 0,89 & {$[0,13-5,76]$} & 4,13 \\
$\mathbf{5}$ & 197.896 & 1.748 & 1.248 & 0 & 0,00 & {$[0,00-0,00]$} & - \\
\hline Total & $\mathbf{1 . 3 6 7 . 3 9 9}$ & $\mathbf{1 7 . 7 2 5}$ & $\mathbf{7 . 7 5 6}$ & $\mathbf{2}$ & $\mathbf{0 , 0 6}$ & {$[\mathbf{0 , 0 1 - 0 , 4 0 ]}$} & $\mathbf{4 , 3 9}$ \\
\hline
\end{tabular}

Além do programa SPSS, também foi utilizado o EPITABLE, que faz parte do programa EPI INFO, para calcular o intervalo de confiança da prevalência de focos de brucelose bovina em cada área. Foi possível utilizá-lo nesses casos porque para cada estrato tem-se uma amostra aleatória de propriedades.

No cálculo do intervalo de confiança para o Estado isso não foi possível, pois se trata de uma amostra estratificada. Quando a prevalência é $0,00 \%$, o SPSS não calcula o intervalo de confiança para os estratos na análise de amostras complexas, estimando esse intervalo como sendo 0,00\%. Sendo assim, o intervalo de confiança para a prevalência de focos no Estado está subestimado pois, no seu cálculo, as 
áreas 1, 2, 3 e 5 não contribuíram com erros e isto explica o intervalo menor obtido para o Estado do que o obtido para cada área pelo EPITABLE.

Para a prevalência de animais soropositivos também não foi possível utilizar o EPITABLE, pois nesse caso trata-se de uma amostra por cluster. É importante ressaltar que o simples fato do programa SPSS não calcular o intervalo de confiança quando a prevalência é $0,00 \%$ não significa que a prevalência seja realmente $0,00 \%$.

O efeito do desenho é a razão da variância da estimativa obtida pelo estudo com a variância da estimativa supondo que os mesmos dados tivessem vindo de uma amostra aleatória simples (COCHRAN, 1977 ).

\subsection{Caracterização epidemiológica}

Para verificar se a distribuição das variáveis quantitativas é semelhante nas cinco áreas, o primeiro passo é identificar o tipo de teste estatístico a ser utilizado. Para isso, foi realizado um teste de hipóteses para saber se elas apresentam distribuição normal. O resultado obtido foi de que, com exceção da distribuição da variável bovinos machos castrados/total bovinos da área $1(p=0,151)$, as demais variáveis quantitativas não apresentam distribuição normal $(p<0,05)$. Como conseqüência, o teste estatístico escolhido foi um teste não-paramétrico (teste de Kruskal-Wallis).

No teste de Kruskal-Wallis, com exceção da variável bovinos fêmeas de 0 a 6 meses $(p=0,276)$, as demais variáveis quantitativas tiveram como resultado $p<0,05$, ou seja, há diferença estatística entre as cinco áreas, no que se refere às suas 
medianas.

Os resultados dos testes não-paramétricos de comparação múltipla, realizados para verificar onde ocorrem essas diferenças, estão detalhados posteriormente, assim como os resultados das análises realizadas com as variáveis qualitativas.

Foram assinaladas as semelhanças existentes entre as áreas porque um dos objetivos do estudo é verificar se é possível agrupá-las.

A análise das variáveis do questionário foi subdividida de modo a permitir uma melhor caracterização epidemiológica das propriedades.

\subsubsection{Características gerais das propriedades}

Para facilitar a compreensão do que se segue, sugere-se a leitura acompanhando-se, paralelamente, o quadro apresentado no Apêndice A.

\subsubsection{Tipo de exploração}

Nas áreas 1, 2, 3 e 4 predominam a exploração mista, sendo estatisticamente iguais as áreas 1,3 e $4(p=0,443)$. A área 1 é a que apresenta maior quantidade de gado de corte e a área 5 difere das demais por possuir o predomínio de gado de leite (Tabela 6). 
São estatisticamente iguais as áreas 2,3 e $4(p=0,064)$ em relação à porcentagem de gado de corte e as áreas 3 e $4 \quad(p=0,270)$ em relação à porcentagem de gado de leite.

Tabela 6 - Freqüência do tipo de exploração segundo a área - Santa Catarina, 2001

\begin{tabular}{|c|c|c|c|}
\hline ÁREA & CORTE & LEITE & MISTA \\
\hline AREA & (IC 95\%) & (IC 95\%) & (IC 95\%) \\
\hline 1 & $35,12(29,71-40,82)$ & $12,37(8,86-16,65)$ & $52,51(46,68-58,29)$ \\
\hline 2 & $10,40(7,18-14,44)$ & $30,87(25,67-36,46)$ & $58,39(52,56-64,04)$ \\
\hline 3 & $8,08(5,59-11,22)$ & $42,42(37,50-47,46)$ & $48,23(43,21-53,28)$ \\
\hline 4 & $13,71(10,02-18,14)$ & $38,80(33,24-44,57)$ & $47,49(41,71-53,32)$ \\
\hline 5 & $6,76(4,17-10,24)$ & $56,76(50,90-62,48)$ & $35,14(29,70-40,87)$ \\
\hline TOTAL & $14,42(12,73-16,25)$ & $36,59(34,21-39,01)$ & $48,36(45,88-50,85)$ \\
\hline
\end{tabular}

\subsubsection{Tipo de criação}

Todas as áreas possuem criação predominantemente extensiva, sendo que a área 1 a possui quase que em sua totalidade (Tabela 7).

As áreas 2, 3 e 4 são estatisticamente iguais tanto em relação à porcentagem de criação semi-confinada $(p=0,379)$ como em relação à porcentagem de criação extensiva $(p=0,371)$. 
Tabela 7 - Freqüência do tipo de criação segundo a área - Santa Catarina, 2001

\begin{tabular}{|c|c|c|c|}
\hline & CONFINADO & SEMI-CONFINADO & EXTENSIVO \\
\hline AREA & $\% \quad($ IC $95 \%)$ & $\% \quad$ (IC 95\%) & $\% \quad$ (IC 95\%) \\
\hline 1 & $0,00(0,00-1,23)$ & $4,35(2,33-7,32)$ & $95,65(92,68-97,66)$ \\
\hline 2 & $0,34(0,00-1,88)$ & $25,17(20,34-30,49)$ & $73,15(67,74-78,10)$ \\
\hline 3 & $0,51(0,06-1,81)$ & $29,29(24,85-34,04)$ & $67,93(63,08-72,50)$ \\
\hline 4 & $0,67(0,08-2,39)$ & $26,42(21,51-31,80)$ & $72,91(67,49-77,86)$ \\
\hline 5 & $1,35(0,37-3,42)$ & $42,57(36,86-48,42)$ & $55,07(49,20-60,83)$ \\
\hline TOTAL & $0,57(0,26-1,07)$ & $25,76(23,62-27,98)$ & $72,67(70,41-74,85)$ \\
\hline
\end{tabular}

\subsubsection{Número de bovinos}

Em relação ao número total de bovinos, a área 1 é a que apresenta maior mediana (16 bovinos por propriedade). As áreas 2 e 5 e as áreas 4 e 5 são estatisticamente iguais (Figura 2).

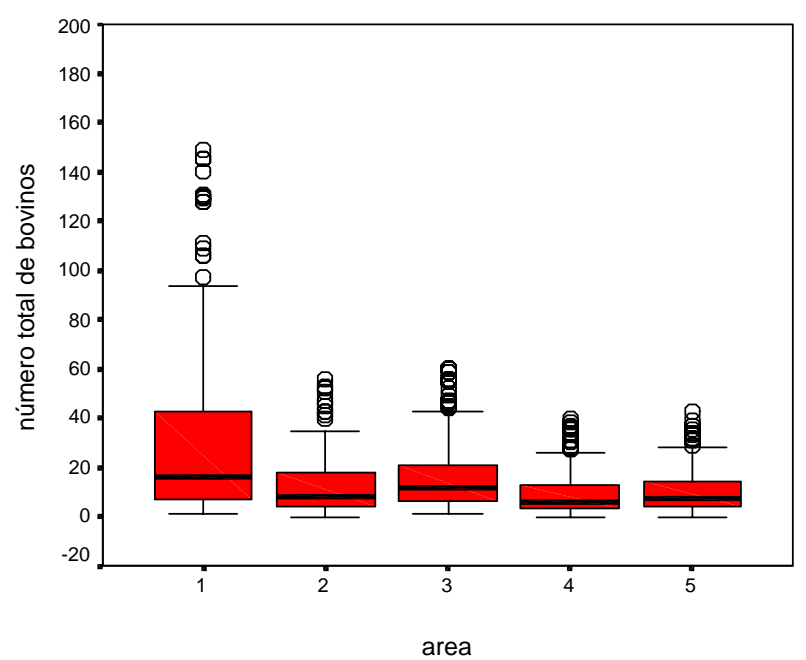

Figura 2 - Diagrama de blocos do número total de bovinos segundo a área 
Analisando a mediana da proporção de bovinos segundo sexo e faixa etária em relação ao total de bovinos, temos:

- bovinos machos castrados: as áreas 1, 2, 3 e 4 e as áreas 2, 4 e 5 são estatisticamente iguais (Figura 3);

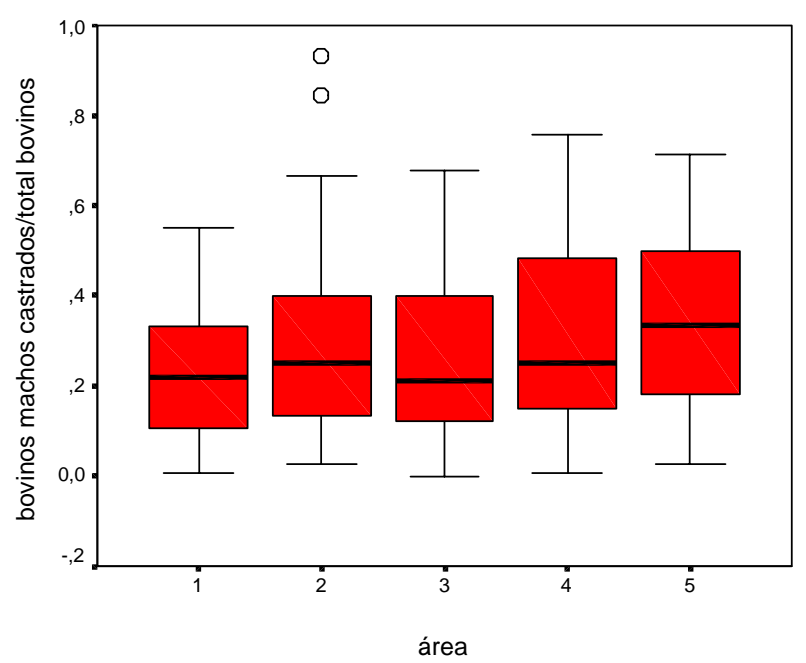

Figura 3 - Diagrama de blocos do número de bovinos machos castrados/total de bovinos segundo a área

- bovinos machos de 0 a 6 meses: as áreas 1, 2, 4 e 5 e as áreas 2, 3 e 5 são estatisticamente iguais (Figura 4);

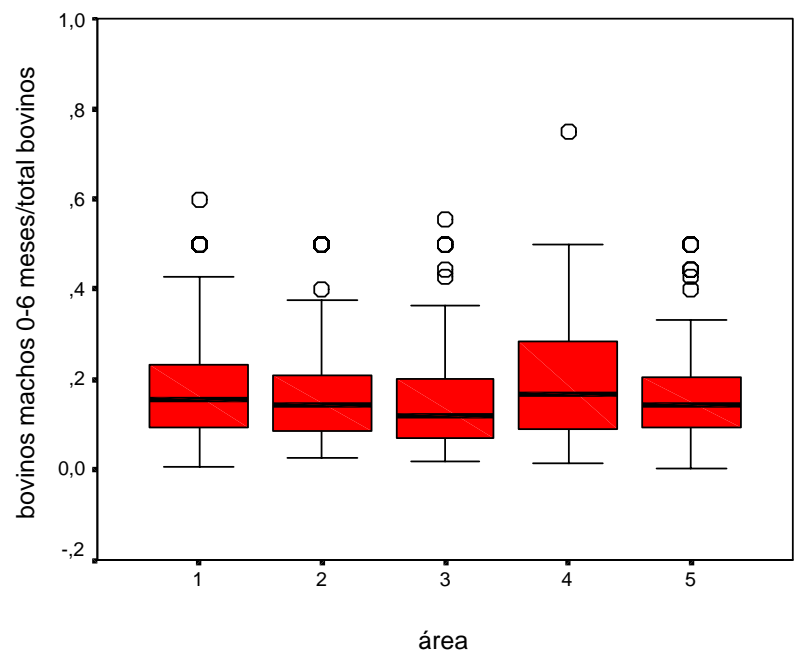

Figura 4 - Diagrama de blocos do número de bovinos machos de 0 a 6 meses/total de bovinos segundo a área 
- bovinos machos de 6 a 12 meses: as áreas 1, 2, 3 e 5 e as áreas 1, 4 e 5 são estatisticamente iguais (Figura 5);

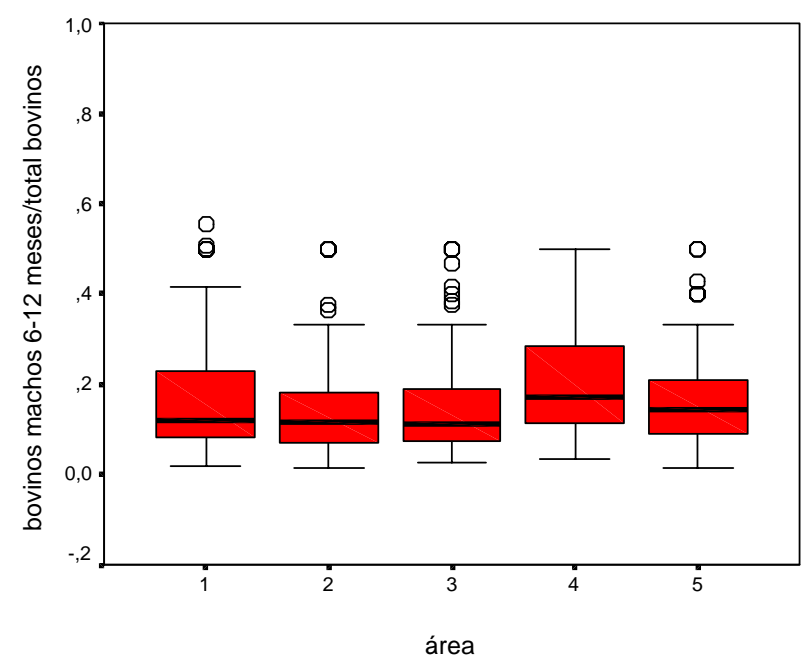

Figura 5 - Diagrama de blocos do número de bovinos machos de 6 a 12 meses/total de bovinos segundo a área

- bovinos machos com idade igual ou superior a

12 meses: as áreas 1, 3, 4 e 5 e as áreas 1, 2 e 5 são estatisticamente iguais (Figura 6);

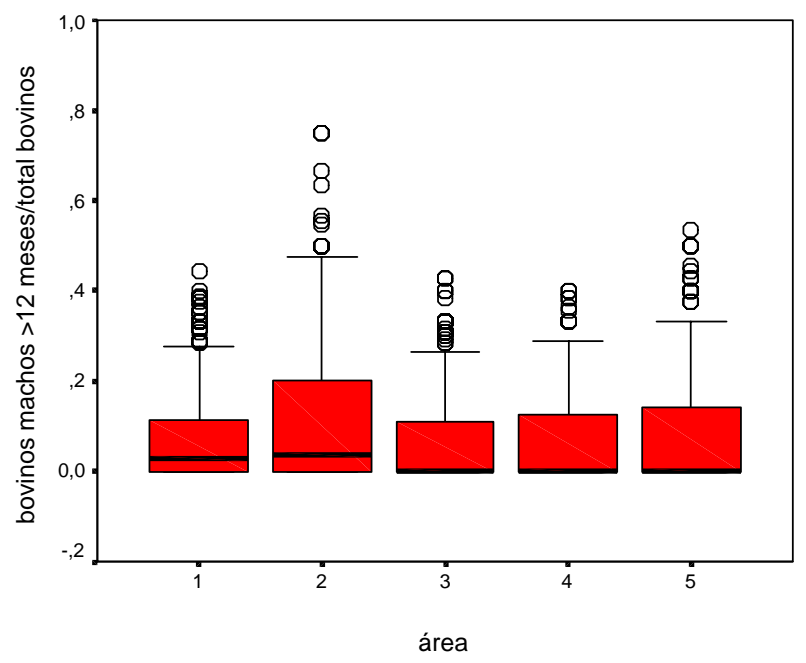

Figura 6 - Diagrama de blocos do número de bovinos machos $\geq 12$ meses/total de bovinos segundo a área 
- bovinos fêmeas de 0 a 6 meses: as cinco áreas são estatisticamente iguais (Figura 7);

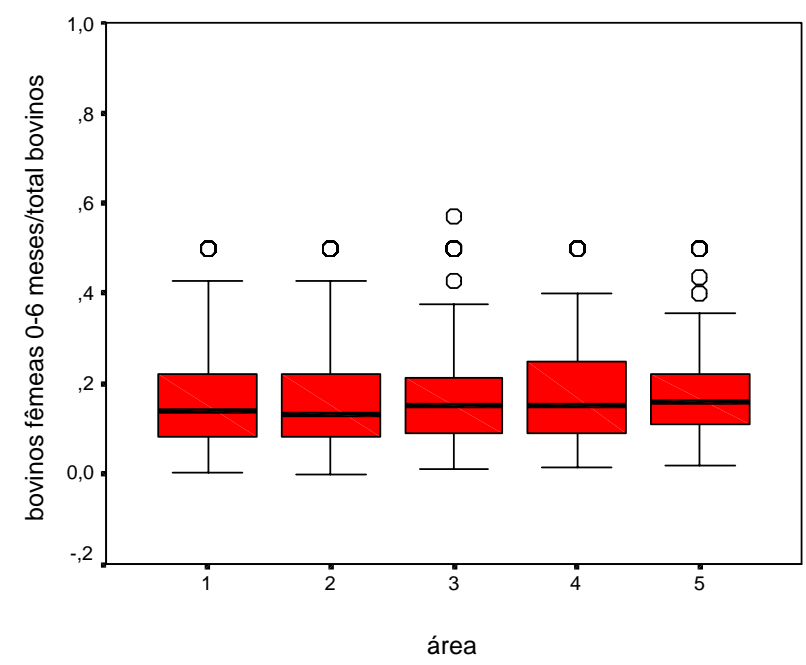

Figura 7 - Diagrama de blocos do número de bovinos fêmeas de 0 a 6 meses/total de bovinos segundo a área

- bovinos fêmeas de 6 a 12 meses: as áreas 1, 2, 3 e 5 e as áreas 2 e 4 são estatisticamente iguais (Figura 8);

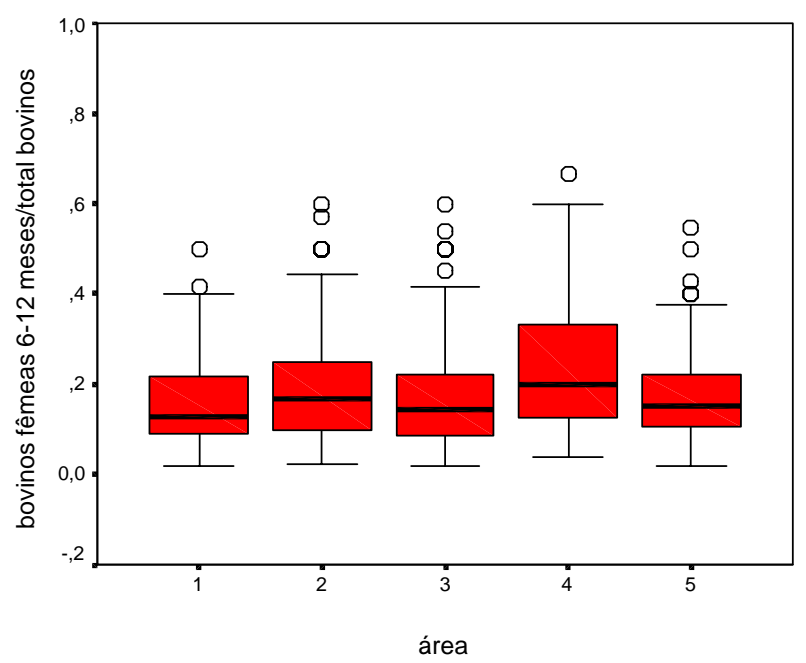

Figura 8 - Diagrama de blocos do número de bovinos fêmeas de 6 a 12 meses/total de bovinos segundo a área 
- bovinos fêmeas com idade igual ou superior a 12 meses: as áreas 1 e 4 e as áreas 3, 4 e 5 são estatisticamente iguais (Figura 9).

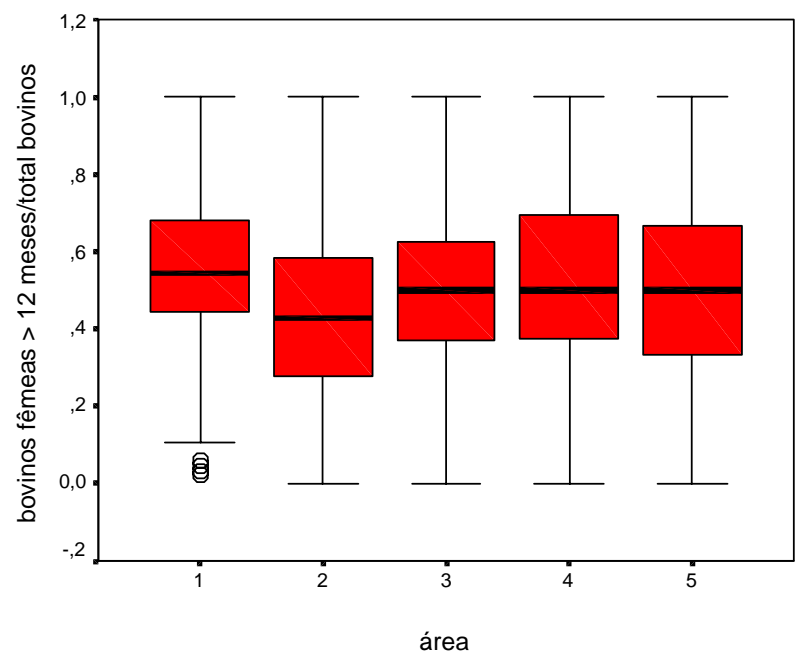

Figura 9 - Diagrama de blocos do número de bovinos fêmeas $\geq 12$ meses/total de bovinos segundo a área

\subsubsection{Raça de bovinos}

Nas cinco áreas há um predomínio de bovinos mestiços (Tabela 8), sendo estatisticamente iguais as áreas 1,2 e $5(p=0,212)$ e 3 e $4(p=0,394)$ em relação à essa porcentagem.

As áreas 3, 4 e 5 são estatisticamente iguais em relação à porcentagem de bovinos europeus de leite $(p=0,119)$, assim como as áreas 1 e $2(p=0,911)$ e 3 e 5 $(p=0,776)$ em relação à porcentagem de bovinos zebuínos. 
Tabela 8 - Freqüência da raça de bovinos segundo a área - Santa Catarina, 2001

\begin{tabular}{|c|c|c|c|c|c|c|}
\hline \multirow[t]{2}{*}{ ÁREA } & \multirow{2}{*}{\multicolumn{2}{|c|}{$\begin{array}{l}\text { ZEBU } \\
\text { (IC 95\%) }\end{array}$}} & \multirow[t]{2}{*}{$\begin{array}{l}\text { EUROPEU LEITE } \\
\% \quad \text { (IC 95\%) }\end{array}$} & \multirow[t]{2}{*}{$\begin{array}{l}\text { EUROPEU } \\
\text { CORTE } \\
\% \quad \text { (IC 95\%) }\end{array}$} & \multirow[t]{2}{*}{ MESTIÇO } & \multirow[t]{2}{*}{$\begin{array}{l}\text { OUTROS } \\
\% \quad \text { (IC 95\%) }\end{array}$} \\
\hline & & & & & & \\
\hline 1 & 10,7 & 77) & 9,03 (b, & $14,39)$ & $68,90(63$ & 0,$6 ;$ \\
\hline 2 & 10 & $(6,89-14,06)$ & 22) & 0,34 & 64 & 0) \\
\hline 3 & 3,03 & $(1$, & $34,09(29,43-38,99)$ & $3,28(1$ & $53,79(4$ & 20) \\
\hline 4 & 0,33 & $(0, c$ & $40,13(34,53-45,93)$ & $6,02(3$, & $53,18(47$ & 0,00 \\
\hline 5 & 38 & $(1,63-6,12)$ & $30,07(24,90-35,64)$ & $1,01(0,21-2,93)$ & $58,45(52,60-64,12)$ & $1,01(0,21-2,93)$ \\
\hline$\overline{\mathrm{AL}}$ & 5,35 & $(4,30-6,58)$ & $27,33(25,15-29,59)$ & $4,16(3,23-5,26)$ & $59,32(56,86-61,75)$ & $0,63(0,30-1,16)$ \\
\hline
\end{tabular}

\subsubsection{Ordenha}

O tipo de ordenha predominante nas propriedades leiteiras e mistas é a manual (Tabela 9), sendo estatisticamente iguais as áreas 2, 3, 4 e 5 ( $p=0,069)$.

São estatisticamente iguais as áreas 2, 4 e $5(p=0,657)$ em relação à ordenha mecânica ao pé e as cinco áreas $(p=0,313)$ em relação à ordenha mecânica em sala de ordenha.

Tabela 9 - Freqüência do tipo de ordenha das propriedades leiteiras e mistas segundo a área - Santa Catarina, 2001

\begin{tabular}{cccccc}
\hline \multirow{2}{*}{ ÁREA } & $\begin{array}{c}\text { NÃO ORDENHA } \\
\text { \% }\end{array}$ & $\begin{array}{c}\text { MANUAL } 95 \%) \\
\text { (IC 95\%) }\end{array}$ & $\begin{array}{c}\text { MECÂNICA AO PÉ } \\
\text { \% }\end{array}$ & $\begin{array}{c}\text { MECÂNICA EM } \\
\text { (IC 95\%) }\end{array}$ & $\begin{array}{c}\text { MALA ORDENHA } \\
\text { \% }\end{array}$ \\
\hline $\mathbf{1}$ & $\mathbf{\text { IC 95\%) }}$ \\
\hline $\mathbf{2}$ & $5,15(2,50-9,28)$ & $91,24(86,34-94,81)$ & $1,03(0,13-3,67)$ & $2,58(0,84-5,91)$ \\
$\mathbf{3}$ & $3,76(1,82-6,80)$ & $80,83(75,57-85,38)$ & $9,02(5,87-13,13)$ & $1,13(0,23-3,26)$ \\
$\mathbf{4}$ & $1,39(0,45-3,22)$ & $77,99(73,35-82,17)$ & $15,04(11,51-19,17)$ & $3,62(1,94-6,11)$ \\
$\mathbf{5}$ & $2,71(1,10-5,51)$ & $79,84(74,42-84,57)$ & $7,36(4,49-11,26)$ & $3,88(1,87-7,01)$ \\
\hline TOTAL & $2,94(1,28-5,71)$ & $81,99(76,89-86,37)$ & $6,99(4,26-10,69)$ & $2,57(1,04-5,23)$ \\
\hline
\end{tabular}


Analisando-se o número de ordenhas das propriedades leiteiras e mistas, notamos que, com exceção das propriedades da área 1, cuja maioria ordenha 1 vez ao dia, as demais ordenham 2 ou 3 vezes por dia, predominantemente (Tabela 10).

As propriedades que ordenham 1 vez por dia pertencentes às áreas 2 e 4 $(p=0,449)$ e 3 e $5(p=0,313)$ são estatisticamente iguais. Já em relação às propriedades que ordenham 2 ou 3 vezes por dia, temos que apenas as pertencentes às áreas 2 e $4(p=0,269)$ são estatisticamente iguais.

Tabela 10 - Freqüência do número de ordenhas das propriedades leiteiras e mistas segundo a área - Santa Catarina, 2001

\begin{tabular}{|c|c|c|c|}
\hline ÁREA & NÃO ORDENHA & 1 VEZ AO DIA & 2 OU 3 VEZES AO DIA \\
\hline AREA & $\% \quad$ (IC 95\%) & (IC 95\%) & $\% \quad$ (IC 95\%) \\
\hline 1 & $4,64(2,14-8,62)$ & $84,02(78,09-88,88)$ & $10,82(6,83-16,07)$ \\
\hline 2 & $6,77(4,06-10,48)$ & $30,83(25,33-36,76)$ & $60,90(54,76-66,80)$ \\
\hline 3 & $1,95(0,79-3,98)$ & $10,03(7,12-13,61)$ & $87,19(83,28-90,46)$ \\
\hline 4 & $5,04(2,71-8,46)$ & $27,13(21,80-32,99)$ & $63,95(57,77-69,82)$ \\
\hline 5 & $5,15(2,84-8,49)$ & $12,5(8,81-17,03)$ & $80,88(75,70-85,38)$ \\
\hline TOTAL & $4,52(3,48-5,77)$ & $28,54(26,14-31,03)$ & $65,31(62,70-67,85)$ \\
\hline
\end{tabular}

\subsubsection{Produção de leite}

As áreas 2 e 5, 3 e 4 e 4 e 5 são estatisticamente iguais em relação à produção diária de leite, sendo que a área 3 possui a maior mediana (7,50 litros) (Figura 10). 


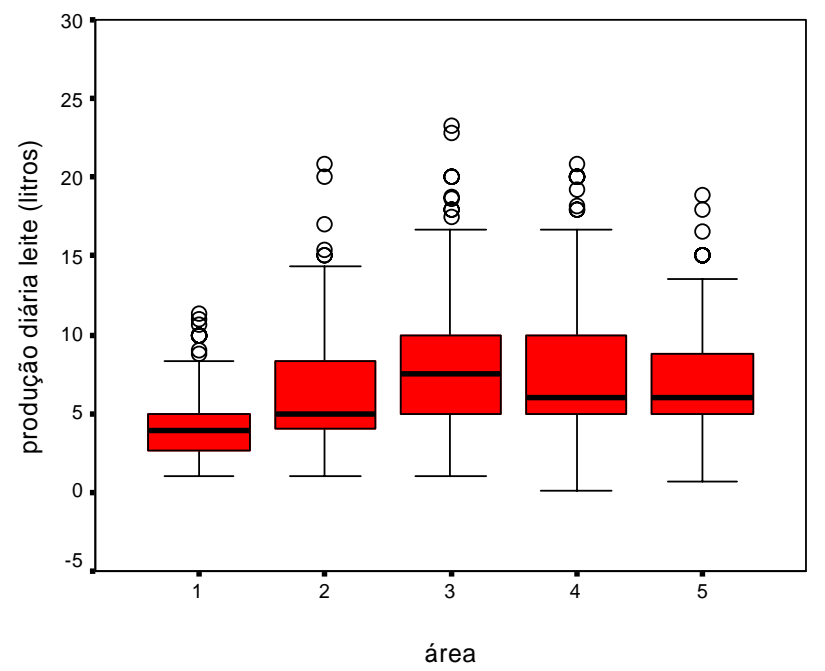

Figura 10 - Diagrama de blocos da produção diária de leite (litros) segundo a área

\subsubsection{Resfriamento do leite}

Com exceção das propriedades leiteiras da área 3, a maioria não faz o resfriamento do leite, conforme mostra a Tabela 11.

As porcentagens das propriedades que fazem o resfriamento do leite das áreas 2, 4 e 5 são estatisticamente iguais $(p=0,671)$. Levando-se em consideração apenas as propriedades leiteiras, são estatisticamente iguais as porcentagens das áreas 1, 2, 4 e $5(p=0,121)$.

$92,47 \%(89,31-94,94 \%)$ das propriedades que fazem o resfriamento do leite utilizam resfriador ou tanque próprio, sendo que as porcentagens das cinco áreas são estatisticamente iguais, tanto quando se analisam todas as propriedades $(p=0,274)$, como quando se analisam apenas as propriedades leiteiras $(p=0,787)$. 
Tabela 11 - Freqüência de propriedades que fazem o resfriamento do leite segundo o tipo de exploração e a área - Santa Catarina, 2001

\begin{tabular}{|c|c|c|c|}
\hline ÁREA & $\begin{array}{c}\text { TODAS AS PROPRIEDADES } \\
\% \quad \text { (IC 95\%) }\end{array}$ & $\begin{array}{c}\begin{array}{l}\text { PROPRIEDADES LEITEIRAS } \\
\% \quad \text { (IC 95\%) }\end{array} \\
\end{array}$ & $\begin{array}{c}\text { PROPRIEDADES MISTAS } \\
\% \quad \text { (IC 95\%) }\end{array}$ \\
\hline 1 & $6,69(4,13-10,14)$ & $18,92(7,96-35,15)$ & $8,28(4,48-13,74)$ \\
\hline 2 & $15,44(11,53-20,05)$ & $27,17(18,42-37,45)$ & $11,49(7,16-17,19)$ \\
\hline 3 & $48,23(43,21-53,28)$ & $66,07(58,38-73,19)$ & $38,74(31,80-46,04)$ \\
\hline 4 & $17,73(13,57-22,53)$ & $36,21(27,49-45,65)$ & $6,34(2,94-11,69)$ \\
\hline 5 & $20,95(16,45-26,03)$ & $27,38(20,79-34,78)$ & $15,38(9,06-23,78)$ \\
\hline TOTAL & $23,43(21,36-25,59)$ & $39,76(35,75-43,87)$ & $17,19(14,58-20,05)$ \\
\hline
\end{tabular}

\subsubsection{Inseminação artificial}

A maioria das propriedades das cinco áreas não utiliza inseminação artificial (Tabela 12), sendo estatisticamente iguais as porcentagens das propriedades das áreas 3 e $5(p=0,113)$.

As áreas 2 e $4(p=0,101)$ e as áreas 3 e $5(p=0,529)$ são estatisticamente iguais em relação à porcentagem de propriedades que utilizam inseminação artificial e touro. Quanto à porcentagem de propriedades que utilizam apenas inseminação artificial, são estatisticamente iguais as áreas 1 e $4(p=0,514)$.

Tabela 12 - Freqüência da utilização de inseminação artificial segundo a área Santa Catarina, 2001

\begin{tabular}{|c|c|c|c|}
\hline ÁREA & $\begin{array}{l}\text { NÃO USA } \\
\% \quad \text { (IC 95\%) }\end{array}$ & 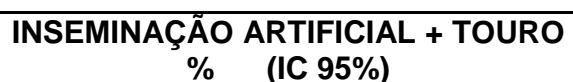 & $\begin{array}{c}\text { INSEMINAÇÃO ARTIFICIAL } \\
\% \quad \text { (IC 95\%) }\end{array}$ \\
\hline 1 & $93,98(90,49-96,29)$ & $4,68(2,58-7,73)$ & $1,34(0,36-3,39)$ \\
\hline 2 & $73,83(68,44-78,72)$ & $15,10(11,23-19,68)$ & $6,71(4,15-10,17)$ \\
\hline 3 & $54,29(49,24-59,28)$ & $25,25(21,05-29,83)$ & $15,91(12,45-19,89)$ \\
\hline 4 & $85,95(81,49-89,68)$ & $11,04 \quad(7,72-15,15)$ & $2,01(0,74-4,32)$ \\
\hline 5 & $49,32(43,49-55,17)$ & $23,65(18,92-28,91)$ & $24,32(19,55-29,62)$ \\
\hline$\overline{T \text { TOTAL }}$ & $70,47(68,15-72,70)$ & $16,50(14,70-18,42)$ & $10,39(8,93-12,00)$ \\
\hline
\end{tabular}


4.3.2 Fatores de risco de brucelose em animais

Os resultados referentes aos fatores de risco de brucelose em animais estão apresentados a seguir.

\subsubsection{Outras espécies na propriedade}

Na maioria das propriedades há aves, cães e gatos. Há eqüinos na maioria das propriedades das áreas 1 e 4 e suínos na maioria das propriedades das áreas 1 , 3, 4 e 5 (Tabela 13).

São estatisticamente iguais as áreas:

- 2 e $3(p=0,225)$, em relação à porcentagem de propriedades que possuem eqüinos;

- 4 e $5(p=0,205)$, em relação à porcentagem de propriedades que possuem suínos;

- 1 , 4 e $5(p=0,536)$, em relação à porcentagem de propriedades que possuem aves;

- 1 e $3(p=0,632)$ e 4 e $5(p=0,778)$, em relação à porcentagem de propriedades que possuem cães;

- 1 e $3(p=0,296)$ e 2, 4 e $5(p=0,176)$, em relação à porcentagem de propriedades que possuem gatos. 
Tabela 13 - Freqüência da presença de outras espécies de animais domésticos na propriedade segundo a área - Santa Catarina, 2001

\begin{tabular}{cccccccc}
\hline ÁREA & $\begin{array}{c}\text { EQUINO } \\
\text { \% IC 95\%) }\end{array}$ & $\begin{array}{c}\text { SUÍNO } \\
\text { (IC 95\%) }\end{array}$ & $\begin{array}{c}\text { AVE } \\
\text { (IC 95\%) }\end{array}$ & $\begin{array}{c}\text { CÃO } \\
\text { (IC 95\%) }\end{array}$ & $\begin{array}{c}\text { GATO } \\
\text { \% }\end{array}$ \\
\hline $\mathbf{1}$ & $78,60(73,51-83,11)$ & $53,18(47,35-58,94)$ & $81,61(76,74-85,83)$ & $89,30(85,23-92,56)$ & $81,61(76,74-85,83)$ \\
$\mathbf{2}$ & $20,81(16,34-25,86)$ & $42,62(36,93-48,45)$ & $71,14(65,63-76,22)$ & $76,51(71,28-81,21)$ & $60,07(54,26-65,67)$ \\
$\mathbf{3}$ & $17,17(13,59-21,25)$ & $80,05(75,77-83,87)$ & $89,65(86,22-92,47)$ & $90,40(87,07-93,12)$ & $84,60(80,66-88,01)$ \\
$\mathbf{4}$ & $67,89(62,27-73,15)$ & $60,87(55,08-66,44)$ & $84,95(80,38-88,80)$ & $83,61(78,92-87,62)$ & $59,53(53,73-65,14)$ \\
$\mathbf{5}$ & $40,88(35,22-46,71)$ & $65,88(60,17-71,26)$ & $83,78(79,08-87,79)$ & $84,46(79,82-88,39)$ & $66,22(60,52-71,59)$ \\
\hline TOTAL & $\mathbf{4 3 , 3 9}(\mathbf{4 0 , 9 3 - 4 5 , 8 7 )}$ & $\mathbf{6 1 , 7 1 ( 5 9 , 2 7 - 6 4 , 1 1 )}$ & $\mathbf{8 2 , 6 8 ( 8 0 , 7 3 - 8 4 , 5 1 )}$ & $\mathbf{8 5 , 2 0 ( 8 3 , 3 6 - 8 6 , 9 1 )}$ & $\mathbf{7 1 , 2 8}(\mathbf{6 8 , 9 9 - 7 3 , 5 0 )}$ \\
\hline
\end{tabular}

Apenas a área 1 possui espécies silvestres em vida livre na maioria das suas propriedades. Nas propriedades onde há animais silvestres, a maioria possui cervídeos (áreas 1 e 3) e capivaras (áreas 2 e 5) (Tabela 14).

São estatisticamente iguais as áreas:

- 3 e $5(p=0,427)$, em relação à porcentagem de propriedades que possuem cervídeos;

- 1 e $2(p=0,222)$, em relação à porcentagem de propriedades que possuem capivaras;

- 1,2 e $3(p=0,716)$, em relação à porcentagem de propriedades que possuem outros animais silvestres.

Tabela 14 - Freqüência da presença de animais silvestres na propriedade segundo a área Santa Catarina, 2001

\begin{tabular}{|c|c|c|c|c|}
\hline ÁREA & ANIMAIS SILVESTRES & CERVÍDEOS & CAPIVARAS & OUTROS \\
\hline 1 & $55,18(49,35-60,91)$ & $87,27(81,21-91,95)$ & $43,03(35,36-50,96)$ & $\begin{array}{c}\% \quad \text { (IC 95\%) } \\
46,67(38,87-54,58)\end{array}$ \\
\hline 2 & $7,05(4,41-10,57)$ & $4,76(0,12-23,82)$ & $57,14(34,02-78,18)$ & $38,10(18,11-61,56)$ \\
\hline 3 & $14,65(11,31-18,52)$ & $56,90(43,23-69,84)$ & $29,31(18,09-42,73)$ & $48,28(34,95-61,78)$ \\
\hline 4 & $0,00(0,00-1,23)$ & - & - & - \\
\hline 5 & $1,01(0,21-2,93)$ & $33,33(0,84-90,57)$ & $100,00(29,24-100,00)$ & $0,00(0,00-70,76)$ \\
\hline TOTAL & $15,55(13,81-17,43)$ & $72,47(66,45-77,94)$ & $41,70(35,48-48,12)$ & $45,75(39,42-52,18)$ \\
\hline
\end{tabular}




\subsubsection{Destino do aborto}

A maioria das propriedades não teve vacas que abortaram nos 12 meses que antecederam a aplicação do questionário (Tabela 15).

São estatisticamente iguais as porcentagens das propriedades das áreas 1, 2, 4 e $5(p=0,570)$ que tiveram ocorrência de aborto durante o período mencionado acima.

Tabela 15 - Ocorrência de aborto na propriedade nos 12 meses que antecederam a aplicação do questionário segundo a área Santa Catarina, 2001

\begin{tabular}{|c|c|c|c|}
\hline ÁREA & NÃO TEVE ABORTO & TEVE ABORTO & NÃO SABE \\
\hline & $\% \quad$ (IC 95\%) & (IC 95\%) & (IC 95\%) \\
\hline 1 & $83,61(78,92-87,62)$ & $13,38(9,73-17,77)$ & $3,01(1,38-5,64)$ \\
\hline 2 & $83,56(78,85-87,58)$ & $9,06(6,05-12,91)$ & $0,00(0,00-1,23)$ \\
\hline 3 & $77,78(73,36-81,78)$ & $17,17(13,59-21,25)$ & $0,76(0,16-2,20)$ \\
\hline 4 & $83,95(79,28-87,92)$ & $12,37(8,86-16,65)$ & $0,00(0,00-1,23)$ \\
\hline 5 & $82,09(77,24-86,29)$ & $11,49(8,09-15,68)$ & $0,00(0,00-1,24)$ \\
\hline TOTAL & $81,93(79,94-83,79)$ & $12,97(11,36-14,73)$ & $0,76(0,39-1,32)$ \\
\hline
\end{tabular}

Quando há aborto, predominantemente não é feito nada (área 1) ou o feto abortado e a placenta são enterrados, jogados ou queimados (áreas 2, 3, 4 e 5), conforme mostra a Tabela 16.

São estatisticamente iguais as áreas 2 e $5(p=0,591)$ e 3 e $4(p=0,350)$ no que se refere a não fazer nada, as cinco áreas $(p=0,701)$ no que se refere a alimentar porco e cão com o feto abortado e a placenta e as áreas 2, 3 e $4(p=0,178)$ e 2, 4 e 5 $(p=0,204)$ no que se refere a enterrá-los, jogá-los ou queimá-los. 
Tabela 16 - Destino do feto abortado e da placenta segundo a área - Santa Catarina, 2001

\begin{tabular}{clccc}
\hline \multirow{2}{*}{ ÁREA } & $\begin{array}{c}\text { NÃO FAZ NADA } \\
\text { \% }\end{array}$ & $\begin{array}{c}\text { ALIMENTA PORCO/CÃO } \\
\text { (IC }\end{array}$ & $\begin{array}{c}\text { ENTERRA/JOGA/QUEIMA } \\
\text { (IC 95\%) }\end{array}$ & $\begin{array}{c}\text { \% } \\
\text { (IC 95\%) }\end{array}$ \\
\hline $\mathbf{1}$ & $85,00(70,16-94,29)$ & $2,50(0,06-13,16)$ & $12,50(4,19-26,80)$ \\
$\mathbf{2}$ & $22,22(8,62-42,26)$ & $3,70(0,09-18,97)$ & $66,67(46,04-83,48)$ \\
$\mathbf{3}$ & $41,18(29,37-53,77)$ & $7,35(2,43-16,33)$ & $50,00(37,62-62,38)$ \\
$\mathbf{4}$ & $32,43(18,01-49,78)$ & $8,11(1,70-21,91)$ & $59,46(42,10-75,24)$ \\
$\mathbf{5}$ & $17,65(6,76-34,53)$ & $2,94(0,07-15,33)$ & $76,47(58,83-89,25)$ \\
\hline TOTAL & $\mathbf{4 1 , 7 5 ( 3 4 , 9 3 - 4 8 , 8 0 )}$ & $\mathbf{5 , 3 4 ( 2 , 7 0 - 9 , 3 5 )}$ & $\mathbf{5 0 , 9 7 ( 4 3 , 9 3 - 5 7 , 9 8 )}$ \\
\hline
\end{tabular}

\subsubsection{Compra e venda de bovinos}

A maioria das propriedades não compra e não vende bovinos com finalidade de reprodução (Tabela 17).

São estatisticamente iguais as porcentagens das propriedades das áreas $1 \mathrm{e}$ 2 em relação à compra $(p=0,675)$ e das áreas 2,3 e 5 em relação à venda de bovinos $(p=0,080)$.

Tabela 17 - Freqüência de compra e venda de bovinos com finalidade de reprodução segundo a área - Santa Catarina, 2001

\begin{tabular}{|c|c|c|}
\hline ÁREA & $\begin{array}{c}\text { COMPRA DE BOVINOS } \\
\% \quad \text { (IC } 95 \%)\end{array}$ & $\begin{array}{c}\text { VENDA DE BOVINOS } \\
\% \quad \text { (IC 95\%) }\end{array}$ \\
\hline 1 & $39,13(33,56-44,91)$ & $26,76(21,82-32,15)$ \\
\hline 2 & $40,27(34,65-46,08)$ & $15,44(11,53-20,05)$ \\
\hline 3 & $31,57(27,01-36,39)$ & $11,36(8,41-14,91)$ \\
\hline 4 & $14,38(10,61-18,88)$ & $5,69(3,35-8,95)$ \\
\hline 5 & $23,65(18,92-28,91)$ & $16,55(12,50-21,29)$ \\
\hline TOTAL & $29,91(27,67-32,23)$ & $14,92(13,21-16,77)$ \\
\hline
\end{tabular}

Tanto a origem da compra como o destino da venda de bovinos é predominantemente outra fazenda (Tabelas 18 e 19). 
As áreas 2, 3, 4 e 5 são estatisticamente iguais no que se refere a origem da compra ser a exposição $(p=0,987)$ ou o leilão ou a feira $(p=0,174)$. Em relação à origem da compra ser o comerciante, são estatisticamente iguais as áreas 1 e 3 $(p=0,517)$ e 4 e $5(p=0,618)$. Quando a origem da compra é outra fazenda, são estatisticamente iguais as áreas 1, 3, 4 e 5 ( $p=0,453)$.

As cinco áreas são estatisticamente iguais quando o destino da venda é a exposição ( $p=0,722)$, o comerciante $(p=0,899)$ ou outra fazenda $(p=0,146)$. Em relação ao destino da venda ser o leilão ou a feira, são estatisticamente iguais as áreas 1,2 e $3(p=0,198)$.

Tabela 18 - Origem da compra de bovinos com finalidade de reprodução segundo a área Santa Catarina, 2001

\begin{tabular}{|c|c|c|c|c|}
\hline \multirow{2}{*}{ ÁREA } & \multirow{2}{*}{$\begin{array}{l}\text { EXPOSIÇÃO } \\
\% \quad \text { (IC 95\%) }\end{array}$} & LEILÃO/FEIRA & COMERCIANTE & \multirow{2}{*}{$\begin{array}{l}\text { OUTRA FAZENDA } \\
\% \quad \text { (IC } 95 \%)\end{array}$} \\
\hline & & $\% \quad$ (IC 95\%) & $\% \quad($ IC 95\%) & \\
\hline 1 & $7,69(3,58-14,10)$ & $12,82(7,36-20,26)$ & $14,53(8,70-22,24)$ & $77,78(69,16-84,94)$ \\
\hline 2 & $1,67(0,20-5,89)$ & $1,67(0,20-5,89)$ & $31,67(23,48-40,78)$ & $60,00(50,66-68,83)$ \\
\hline 3 & $1,60(0,19-5,66)$ & $4,80(1,78-10,15)$ & $17,60(11,37-25,42)$ & $72,00(63,27-79,66)$ \\
\hline 4 & $2,33(0,06-12,29)$ & $4,65(0,57-15,81)$ & $4,65(0,57-15,81)$ & $79,07(63,96-89,95)$ \\
\hline 5 & $1,43(0,04-7,70)$ & $0,00(0,00-5,13)$ & $2,86(0,35-9,94)$ & $81,43(70,34-89,72)$ \\
\hline TOTAL & $3,16(1,78-5,16)$ & $5,26(3,43-7,67)$ & $17,05(13,78-20,74)$ & $72,42(68,17-76,40)$ \\
\hline
\end{tabular}

Tabela 19 - Destino da venda de bovinos com finalidade de reprodução segundo a área Santa Catarina, 2001

\begin{tabular}{|c|c|c|c|c|}
\hline \multirow{2}{*}{ ÁREA } & \multirow{2}{*}{$\begin{array}{l}\text { EXPOSIÇÃO } \\
\% \quad \text { (IC 95\%) }\end{array}$} & \multirow{2}{*}{$\begin{array}{l}\text { LEILÃO/FEIRA } \\
\% \quad \text { (IC 95\%) }\end{array}$} & COMERCIANTE & \multirow{2}{*}{$\begin{array}{l}\text { OUTRA FAZENDA } \\
\% \quad \text { (IC } 95 \%)\end{array}$} \\
\hline & & & $\% \quad$ (IC 95\%) & \\
\hline 1 & $1,25(0,03-6,77)$ & $11,25(5,27-20,28)$ & $22,50(13,91-33,21)$ & $75,00(64,06-84,01)$ \\
\hline 2 & $2,17(0,05-11,53)$ & $2,17(0,05-11,53)$ & $28,26(15,99-43,46)$ & $63,04(47,55-76,79)$ \\
\hline 3 & $0,00(0,00-7,87)$ & $8,89(2,47-21,22)$ & $24,44(12,88-39,54)$ & $60,00(44,33-74,30)$ \\
\hline 4 & $0,00(0,00-19,51)$ & $0,00(0,00-19,51)$ & $17,65(3,80-43,43)$ & $82,35(56,57-96,20)$ \\
\hline 5 & $0,00(0,00-7,25)$ & $0,00(0,00-7,25)$ & $26,53(14,95-41,08)$ & $59,18(44,21-73,00)$ \\
\hline TOTAL & $0,84(0,10-3,02)$ & $5,91(3,27-9,71)$ & $24,47(19,14-30,46)$ & $67,09(60,71-73,03)$ \\
\hline
\end{tabular}




\subsubsection{Manejo}

Na maioria das propriedades não se alugam pastos, não existem pastos em comum com outras propriedades, não há áreas alagadiças em que o gado tenha acesso e não há piquete separado para fêmeas na fase de parto e/ou pós-parto (Tabela 20).

As propriedades das áreas 2, 3, 4 e 5 são estatisticamente iguais em relação a alugar pastos $(p=0,296)$ e a possuir pastos em comum com outras propriedades $(p=0,111)$.

Já em relação a possuir áreas alagadiças em que o gado tenha acesso, são estatisticamente iguais as propriedades das áreas 1,3 e $4(p=0,547)$ e 2 e 5 $(p=0,170)$ e em relação a possuir piquete separado para fêmeas na fase de parto e/ou pós-parto são estatisticamente iguais as áreas 2 e $3(p=0,126)$ e 4 e 5 $(p=0,707)$.

Tabela 20 - Freqüência de tipos de manejo utilizados nas propriedades segundo a área Santa Catarina, 2001

\begin{tabular}{|c|c|c|c|c|}
\hline ÁREA & $\begin{array}{l}\text { ALUGA PASTOS } \\
\% \quad \text { (IC 95\%) }\end{array}$ & $\begin{array}{c}\text { PASTOS EM COMUM } \\
\% \quad \text { (IC 95\%) }\end{array}$ & $\begin{array}{c}\text { ÁREAS ALAGADIÇAS } \\
\% \quad \text { (IC 95\%) }\end{array}$ & $\begin{array}{c}\text { PIQUETE SEPARADO } \\
\% \quad \text { (IC 95\%) }\end{array}$ \\
\hline 1 & $18,06(13,87-22,90)$ & $16,39(12,38-21,08)$ & $20,07(15,68-25,06)$ & $38,13(32,60-43,89)$ \\
\hline 2 & $6,71(4,15-10,17)$ & $12,75(9,18-17,08)$ & $37,92(32,39-43,69)$ & $16,78(12,72-21,51)$ \\
\hline 3 & $4,55(2,71-7,09)$ & $7,83(5,38-10,93)$ & $19,95(16,12-24,23)$ & $12,63(9,52-16,30)$ \\
\hline 4 & $3,68(1,85-6,49)$ & $8,36(5,48-12,09)$ & $23,08(18,42-28,27)$ & $9,03(6,03-12,87)$ \\
\hline 5 & $6,08(3,64-9,44)$ & $10,81(7,51-14,92)$ & $32,43(27,13-38,09)$ & $8,11(5,26-11,82)$ \\
\hline TOTAL & $7,62(6,36-9,04)$ & $11,02(9,52-12,66)$ & $26,26(24,11-28,50)$ & $16,69(14,89-18,61)$ \\
\hline
\end{tabular}

4.3.3 Fatores de risco de brucelose em humanos 
Os resultados referentes aos fatores de risco de brucelose em humanos estão apresentados a seguir.

\subsubsection{Abate}

A maioria das propriedades de corte e mista das áreas 1 e 3 abatem fêmeas e machos adultos no final da vida reprodutiva em estabelecimentos sem inspeção, ao passo que a maioria das propriedades das áreas 2 e 4 não abatem e a maioria das propriedades da área 5 abatem na própria fazenda (Tabela 21).

Levando-se em consideração o não abate, são estatisticamente iguais as porcentagens das propriedades de corte e mista das áreas 1, 2, 3 e $5(p=0,424)$.

Em relação ao abate em estabelecimentos com inspeção, as cinco áreas $(p=0,108)$ são estatisticamente iguais.

Em se tratando de abate em estabelecimentos sem inspeção, são estatisticamente iguais as áreas 2 e $3(p=0,183)$ e 2 e $4(p=0,105)$.

Já em relação ao abate na própria fazenda, as áreas 1 e $4(p=0,899)$ e 2 e 3 $(p=0,136)$ são estatisticamente iguais. 
Tabela 21 - Local de abate das propriedades de corte e mista segundo a área - Santa Catarina, 2001

\begin{tabular}{|c|c|c|c|c|}
\hline ÁREA & $\begin{array}{l}\text { NÃO ABATE } \\
\% \quad \text { (IC 95\%) }\end{array}$ & $\begin{array}{l}\text { ESTABELECIMENTO } \\
\text { COM INSPEÇÃO }\end{array}$ & $\begin{array}{l}\text { ESTABELECIMENTO } \\
\text { SEM INSPEÇÃO }\end{array}$ & $\begin{array}{l}\text { NA PRÕPRIA } \\
\text { FAZENDA }\end{array}$ \\
\hline & & $\% \quad$ (IC 95\%) & $\% \quad($ IC 95\%) & $\% \quad($ IC 95\%) \\
\hline 1 & $28,63(23,23-34,51)$ & $15,27(11,14-20,20)$ & $45,04(38,91-51,28)$ & $10,69(7,22-15,07)$ \\
\hline 2 & $33,66(27,23-40,57)$ & $13,66(9,27-19,13)$ & $23,90(18,24-30,34)$ & $25,85(20,01-32,41)$ \\
\hline 3 & $27,35(21,62-33,79)$ & $21,08(15,92-27,02)$ & $30,04(24,11-36,52)$ & $20,18(15,12-26,05)$ \\
\hline 4 & $49,73(42,27-57,20)$ & $20,22(14,65-26,77)$ & $17,49(12,28-23,78)$ & $10,93(6,80-16,37)$ \\
\hline 5 & $29,03(21,23-37,86)$ & $21,77(14,87-30,08)$ & $7,26(3,37-13,33)$ & $37,10(28,60-46,23)$ \\
\hline TOTAL & $33,95(30,98-37,01)$ & $18,30(15,93-20,87)$ & $28,12(25,32-31,05)$ & $19,63(17,19-22,26)$ \\
\hline
\end{tabular}

\subsubsection{Destino do leite}

A maioria das propriedades leiteiras não entrega o leite, exceto as da área 3, cujo predomínio é a entrega do leite em laticínios (Tabela 22).

São estatisticamente iguais as porcentagens das propriedades leiteiras das áreas 1, 2, 4 e 5 que não entregam $(p=0,870)$ e que entregam o leite em laticínios $(p=0,541)$.

Já em relação à entrega do leite em cooperativas, são estatisticamente iguais as porcentagens das propriedades leiteiras das áreas 2 e $5(p=0,359)$ e 3 e 4 $(p=0,588)$ e em relação à entrega direto ao consumidor, são estatisticamente iguais as das áreas 1 e $2(p=0,752)$ e 3,4 e $5(p=0,199)$. 
Tabela 22 - Destino do leite das propriedades leiteiras segundo a área - Santa Catarina, 2001

\begin{tabular}{|c|c|c|c|c|}
\hline ÁREA & $\begin{array}{c}\text { NÃO ENTREGA } \\
\% \quad(\text { IC } 95 \%)\end{array}$ & $\begin{array}{l}\text { COOPERATIVA } \\
\% \quad \text { (IC } 95 \%)\end{array}$ & \begin{tabular}{l}
\multicolumn{2}{c}{ LATICÍNIO } \\
$\% \quad$ (IC 95\%)
\end{tabular} & $\begin{array}{c}\text { DIRETO AO CONSUMIDOR } \\
\% \quad \text { (IC 95\%) }\end{array}$ \\
\hline 1 & $59,46(42,10-75,24)$ & $0,00(0,00-9,49)$ & $27,03(13,79-44,12)$ & $13,51(4,54-28,77)$ \\
\hline 2 & $54,35(43,63-64,78)$ & $3,26(0,68-9,23)$ & $23,91(15,63-33,94)$ & $15,22(8,58-24,21)$ \\
\hline 3 & $27,98(21,33-35,41)$ & $23,81(17,59-30,98)$ & $43,45(35,83-51,30)$ & $4,76(2,08-9,17)$ \\
\hline 4 & $51,72(42,26-61,10)$ & $20,69(13,73-29,20)$ & $19,83(13,00-28,25)$ & $6,03(2,46-12,04)$ \\
\hline 5 & $55,95(48,10-63,59)$ & $5,95(2,89-10,67)$ & $27,38(20,79-34,78)$ & $9,52(5,54-15,00)$ \\
\hline$\overline{\text { TOTAL }}$ & $46,99(42,87-51,14)$ & $13,25(10,60-16,28)$ & $29,95(26,25-33,85)$ & $8,61(6,45-11,19)$ \\
\hline
\end{tabular}

A maioria das propriedades leiteiras da área 3 entrega o leite a granel (Tabela 23), sendo que as porcentagens das propriedades leiteiras das demais áreas são estatisticamente iguais $(p=0,132)$.

Tabela 23 - Freqüência de entrega de leite a granel das propriedades leiteiras segundo a área - Santa Catarina, 2001

\begin{tabular}{ccc}
\hline \multirow{2}{*}{ ÁREA } & $\begin{array}{c}\text { NÃO ENTREGA LEITE A GRANEL } \\
\text { \% }\end{array}$ & $\begin{array}{c}\text { ENTREGA LEITE A GRANEL } \\
\text { (IC 95) }\end{array}$ \\
\hline $\mathbf{1}$ & $24,32(11,77-41,20)$ & $16,21(6,19-32,01)$ \\
$\mathbf{2}$ & $53,26(42,56-63,74)$ & $31,52(22,23-42,04)$ \\
$\mathbf{3}$ & $35,12(27,92-42,85)$ & $61,31(53,50-68,71)$ \\
$\mathbf{4}$ & $43,97(34,76-53,48)$ & $39,66(30,69-49,16)$ \\
$\mathbf{5}$ & $58,33(50,49-65,88)$ & $27,98(21,33-35,41)$ \\
\hline TOTAL & $45,78(41,68-49,93)$ & $39,76(35,75-43,87)$ \\
\hline
\end{tabular}

\subsubsection{Produção de queijo e/ou manteiga}

A maioria das propriedades leiteiras produz queijo e/ou manteiga, sendo suas porcentagens estatisticamente iguais $(p=0,131)$. A produção é praticamente voltada para o consumo próprio (Tabela 24). 
São estatisticamente iguais as porcentagens das propriedades leiteiras das áreas 1 e $2(p=0,328)$ e 3, 4 e $5(p=0,677)$ que produzem queijo e/ou manteiga para consumo próprio e para a venda.

Tabela 24 - Freqüência da produção de queijo e/ou manteiga e sua finalidade nas propriedades leiteiras segundo a área - Santa Catarina, 2001

\begin{tabular}{|c|c|c|c|}
\hline ÁREA & $\begin{array}{c}\text { PRODUZ QUEIJO EIOU MANTEIGA } \\
\% \quad \text { (IC 95\%) }\end{array}$ & $\begin{array}{c}\text { FINALIDADE: CONSUMO PROPRIO } \\
\% \quad \text { (IC 95\%) }\end{array}$ & $\begin{array}{c}\text { FINALIDADE: VENDA } \\
\% \quad(\text { IC } 95 \%)\end{array}$ \\
\hline 1 & $54,05(36,92-70,51)$ & $70,00(45,72-88,11)$ & $30,00(11,89-54,28)$ \\
\hline 2 & $57,61(46,86-67,85)$ & $79,25(65,89-89,16)$ & $18,87(9,44-31,97)$ \\
\hline 3 & $57,74(49,89-65,31)$ & $91,75(84,39-96,37)$ & $7,22(2,95-14,30)$ \\
\hline 4 & $43,10(33,94-52,62)$ & $90,00(78,19-96,67)$ & $8,00(2,22-19,23)$ \\
\hline 5 & $50,59(42,79-58,38)$ & $85,88(76,64-92,49)$ & $10,59(4,96-19,15)$ \\
\hline TOTAL & $52,50(48,35-56,62)$ & $86,23(81,85-89,89)$ & $11,80(8,41-15,96)$ \\
\hline
\end{tabular}

\subsubsection{Consumo de leite cru}

Com exceção da área 1, na maioria das áreas não ocorre consumo de leite cru (Tabela 25), sendo estatisticamente iguais as porcentagens das áreas 2, 4 e 5 $(p=0,195)$.

Tabela 25 - Freqüência do consumo de leite cru segundo a área Santa Catarina, 2001

\begin{tabular}{ccc}
\hline \multirow{2}{*}{ ÁREA } & NÃO CONSOME LEITE CRU & CONSOME LEITE CRU \\
$\mathbf{\%}$ & (IC 95\%) & (IC 95\%) \\
\hline $\mathbf{1}$ & $32,10(26,85-37,72)$ & $67,89(62,27-73,15)$ \\
$\mathbf{2}$ & $87,58(83,29-91,10)$ & $8,72(5,78-12,52)$ \\
$\mathbf{3}$ & $79,55(75,23-83,41)$ & $19,70(15,89-23,96)$ \\
$\mathbf{4}$ & $85,95(81,49-89,68)$ & $12,37(8,86-16,65)$ \\
$\mathbf{5}$ & $82,77(77,98-86,89)$ & $13,18(9,54-17,57)$ \\
\hline TOTAL & $\mathbf{7 3 , 9 3}(\mathbf{7 1 , 7 0 - 7 6 , 0 7 )}$ & $\mathbf{2 4 , 1 2}(\mathbf{2 2 , 0 3 - 2 6 , 3 0 )}$ \\
\hline
\end{tabular}




\subsubsection{Outros fatores}

Os resultados referentes a outros fatores estão apresentados a seguir.

\subsubsection{Testes para diagnóstico da brucelose}

A maioria das propriedades não faz testes para diagnóstico da brucelose (Tabela 26).

As porcentagens das propriedades das áreas 1,2 e $3(p=0,239)$ e 4 e 5 $(p=0,760)$ que fazem o teste para diagnóstico da brucelose são estatisticamente iguais.

Tabela 26 - Realização de testes para diagnóstico da brucelose segundo a área - Santa Catarina, 2001

\begin{tabular}{ccc}
\hline ÁREA & $\begin{array}{c}\text { NÃO } \\
\text { (IC 95\%) }\end{array}$ & $\begin{array}{l}\text { SIM } \\
\text { (IC 95\%) }\end{array}$ \\
\hline $\mathbf{1}$ & $90,97(87,13-93,96)$ & $9,03(6,03-12,87)$ \\
$\mathbf{2}$ & $88,59(84,42-91,97)$ & $10,07(6,89-14,06)$ \\
$\mathbf{3}$ & $86,87(83,14-90,03)$ & $12,88(9,74-16,58)$ \\
$\mathbf{4}$ & $90,30(86,37-93,41)$ & $6,35(3,87-9,74)$ \\
$\mathbf{5}$ & $91,22(87,39-94,18)$ & $7,09(4,44-10,64)$ \\
\hline TOTAL & $\mathbf{8 9 , 4 2 ( 8 7 , 8 0 - 9 0 , 8 9 )}$ & $\mathbf{9 , 3 2 ( 7 , 9 3 - 1 0 , 8 6 )}$ \\
\hline
\end{tabular}

A regularidade dos testes realizados para o diagnóstico da brucelose é predominantemente 1 vez por ano e quando exigido para trânsito (Tabela 27). 
As cinco áreas são estatisticamente iguais em relação à realização dos testes uma vez por ano $(p=0,186)$, quando se compra animais $(p=0,734)$ e quando há caso de aborto $(p=0,486)$. As áreas 1, 2, 4 e 5 são estatisticamente iguais em relação à realização dos testes duas vezes por ano $(p=0,326)$ e as áreas 1,2 , 3 e 5 quando é exigido para trânsito $(p=0,198)$.

Tabela 27 - Regularidade dos testes para diagnóstico da brucelose segundo a área Santa Catarina, 2001

\begin{tabular}{|c|c|c|c|c|c|}
\hline ÁREA & $\begin{array}{l}1 \text { VEZIANO } \\
\% \quad \text { (IC } 95 \%)\end{array}$ & $\begin{array}{l}2 \text { VEZESIANO } \\
\% \quad \text { (IC } 95 \%)\end{array}$ & $\begin{array}{c}\text { QUANDO } \\
\text { COMPRA ANIMAIS }\end{array}$ & $\begin{array}{l}\text { QUANDO HÁ } \\
\text { ABORTO }\end{array}$ & $\begin{array}{l}\text { QUANDO EXIGIDO } \\
\text { PARA TRÂNSITO }\end{array}$ \\
\hline 1 & 29,6 & 16 & $11,11(2,35-29,16)$ & $0,00(0,00$ & $55,56(35,33-74,52)$ \\
\hline 2 & $40,00(22,65-59,40)$ & $6,67(0,82-22,07)$ & $16,67(5,64-34,72)$ & $6,67(0,82-22,07)$ & $30,00(14,73-49,39)$ \\
\hline 3 & $27,45(15,89-41,74)$ & $0,00(0,00-6,98)$ & $21,57(11,29-35,32)$ & $7,84(2,18-18,88)$ & $43,14(29,34-57,75)$ \\
\hline 4 & $52,63(28,86-75,55)$ & $15,79(3,38-39,58)$ & $15,79(3,38-39,58)$ & $0,00(0,00-17,65)$ & $5,26(0,13-26,03)$ \\
\hline 5 & $33,33(14,59-56,97)$ & $14,29(3,05-36,34)$ & $9,52(1,17-30,38)$ & $4,76(0,12-23,82)$ & $28,57(11,28-52,17)$ \\
\hline TOTAL & $34,46(26,85-42,71)$ & $6,08(2,82-11,23)$ & $16,22(10,68-23,16)$ & $4,73(1,92-9,50)$ & $35,81(28,11-44,10)$ \\
\hline
\end{tabular}

\subsubsection{Vacina}

Praticamente todas as áreas não vacinam os bovinos contra a brucelose, sendo que na área 1 isso ocorre na sua totalidade (Tabela 28).

As porcentagens das propriedades que não vacinam os bovinos nas áreas 2, 3,4 e $5(p=0,083)$ e das que vacinam fêmeas até 8 meses das áreas 3,4 e 5 $(p=0,213)$ são estatisticamente iguais. 
Tabela 28 - Realização de vacinação de bovinos contra a brucelose segundo a área - Santa Catarina, 2001

\begin{tabular}{ccc}
\hline ÁREA & $\begin{array}{c}\text { NÃO VACINA } \\
\%\end{array}$ & $\begin{array}{c}\text { VACINA FÊMEAS ATÉ 8 MESES } \\
\text { (IC 95\%) }\end{array}$ \\
\hline $\mathbf{~ I C ~ 9 5 \% ) ~}$ \\
$\mathbf{2}$ & $100,00(98,77-100,00)$ & $0,00(0,00-1,23)$ \\
$\mathbf{3}$ & $97,32(94,78-98,83)$ & $0,00(0,00-1,23)$ \\
$\mathbf{4}$ & $97,98(96,06-99,12)$ & $0,76(0,16-2,20)$ \\
$\mathbf{5}$ & $97,66(95,24-99,05)$ & $1,67(0,54-3,86)$ \\
\hline TOTAL & $98,99(97,07-99,79)$ & $0,34(0,00-1,88)$ \\
\hline
\end{tabular}

\subsubsection{Assistência veterinária}

A maioria das propriedades das áreas 3 e 5 possuem assistência veterinária (Tabela 29).

As porcentagens das propriedades das áreas 1 e 4 que possuem assistência veterinária são estatisticamente iguais $(p=0,075)$.

Onde há assistência veterinária, esta é feita predominantemente por veterinários particulares (áreas 1 e 2) e por veterinários de cooperativa (áreas 3, 4 e 5), conforme mostra a tabela 29.

São estatisticamente iguais as porcentagens das propriedades das áreas 3 e 4 que possuem assistência veterinária realizada por veterinários de cooperativa $(p=0,468)$ e por veterinários particulares $(p=0,468)$. 
Tabela 29 - Freqüência de propriedades que possuem assistência veterinária e tipo de assistência veterinária segundo a área - Santa Catarina, 2001

\begin{tabular}{ccccc}
\hline \multirow{2}{*}{ ÁREA } & $\begin{array}{c}\text { ASSISTÉNCIA VETERINÁRIA } \\
\text { (IC 95\%) }\end{array}$ & $\begin{array}{c}\text { VETERINÁRIO DE COOPERATIVA } \\
\text { \% }\end{array}$ & $\begin{array}{c}\text { VETERINÁRIO PARTICULAR } \\
\text { (IC 95) }\end{array}$ \\
\hline $\mathbf{1}$ & $34,78(29,39-40,48)$ & $8,65(4,03-15,79)$ & $91,35(84,21-95,97)$ \\
$\mathbf{2}$ & $48,99(43,18-54,82)$ & $33,56(25,97-41,84)$ & $52,74(44,32-61,05)$ \\
$\mathbf{3}$ & $59,85(54,83-64,71)$ & $56,12(49,55-62,54)$ & $29,96(24,20-36,23)$ \\
$\mathbf{4}$ & $41,47(35,83-47,28)$ & $68,55(59,60-76,59)$ & $30,65(22,68-39,56)$ \\
$\mathbf{5}$ & $74,32(68,95-79,20)$ & $41,82(35,22-48,64)$ & $39,55(33,04-46,34)$ \\
\hline TOTAL & $\mathbf{5 2 , 3 3 ( 4 9 , 8 4 - 5 4 , 8 1 )}$ & $\mathbf{4 4 , 2 8 ( 4 0 , 8 7 - 4 7 , 7 4 )}$ & $\mathbf{4 4 , 2 8 ( 4 0 , 8 7 - 4 7 , 7 4 )}$ \\
\hline
\end{tabular}


5 Discussão

"Experiência não é o que acontece com um homem; é o que um homem faz com o que lhe acontece." (Aldous Huxley) 


\section{DISCUSSÃO}

Em relação às características dos rebanhos, a área 1 é a que possui a maior mediana do número de bovinos (16 bovinos por propriedade), a maior porcentagem de gado de corte $(35,12 \%$ [29,71-40,82\%] das propriedades) e é a que mais se diferencia das demais em relação às outras características analisadas.

As áreas 2, 3, 4 e 5 são semelhantes em muitos aspectos, porém algumas diferenças em relação às áreas 3 e 5 merecem destaque.

A área 3 faz o resfriamento do leite em 66,07\% (58,38-73,19\%) das propriedades leiteiras e possui a maior mediana de produção diária de leite $(7,5$ litros), mediana esta que é estatisticamente igual à da área 4 e é superior à da área 5, que ficou caracterizada como sendo a que possui maior porcentagem de propriedades leiteiras. Portanto, apesar de possuir 48,23\% $(43,21-53,28 \%)$ de propriedades de exploração mista e 42,42\% (37,50-47,46\%) de exploração leiteira, a área 3 se comporta mais como leiteira do que mista.

Por sua vez, na área 5, que possui 56,76\% (50,90-62,48\%) de propriedades de exploração leiteira, apenas 6,99\% (4,26-10,69\%) utilizam ordenha mecânica ao pé, 2,57\% (1,04-5,23\%) utilizam ordenha mecânica em sala de ordenha e somente 27,38\% (20,79-34,78\%) fazem o resfriamento do leite. Além disso, a área 5 é a que mais utiliza inseminação artificial.

Pelas características analisadas e pelos resultados obtidos, nota-se que a maioria das propriedades são propriedades familiares, que produzem para o seu próprio consumo.

Comparando as semelhanças existentes entre as áreas (Apêndice A), sugere- 
se que as áreas 3 e 4 sejam agrupadas. Para essa comparação foram analisadas as variáveis relacionadas às características gerais das propriedades, ou seja, o tipo de exploração, o tipo de criação, o número total de bovinos, a proporção de bovinos segundo sexo e faixa etária, a raça dos bovinos, o tipo e o número de ordenhas, a produção de leite, o resfriamento do leite e a utilização de inseminação artificial.

Apesar das diferenças existentes em relação ao resfriamento do leite e à inseminação artificial, as áreas 3 e 4 possuem freqüências estatisticamente iguais em relação à muitas variáveis consideradas nessa análise e que são importantes na caracterização das propriedades, como por exemplo, tipo de exploração e de criação, raça, tipo de ordenha e produção de leite (Apêndice A).

A sugestão de união de duas áreas também pode ser útil para programas de controle e erradicação de outras doenças. A divisão de um Estado em áreas auxilia na escolha das melhores estratégias de ação, ou seja, decisões direcionadas podem ser tomadas para cada área específica. Já que duas áreas possuem características semelhantes, a união das mesmas facilitaria ainda mais as medidas de controle e erradicação.

A prevalência de focos de brucelose bovina obtida neste estudo foi de $0,02 \%$ $(0,00-0,15 \%)$. Para esse cálculo foi utilizada a amostragem aleatória estratificada, onde cada uma das áreas foi considerada como sendo um estrato. A estratificação tende a reduzir a variância, ou seja, diminui o intervalo de confiança e, como apenas na área 4 a prevalência não foi 0,00\%, quando se calcula o intervalo de confiança no Estado de Santa Catarina, o programa SPSS considera apenas a incerteza dessa área. Apesar das demais áreas terem prevalência estimada igual a 0,00\%, pode-se considerar que em cada área tem-se uma amostra aleatória de propriedades e, nesse caso, pode-se utilizar o EPITABLE para calcular o intervalo de confiança de 
cada uma das áreas (resultado apresentado na Tabela 4). Assim, pode-se verificar que a incerteza para cada uma das áreas é certamente maior que 0,00\%, porém os programas disponíveis para análise de amostras complexas consideram, no cálculo da prevalência por área, as incertezas como sendo 0,00\% e sendo assim, acabam subestimando a incerteza na prevalência do Estado.

Não foi possível utilizar o EPITABLE para o cálculo do intervalo de confiança da prevalência de animais soropositivos, pois nesse caso trata-se de uma amostragem por cluster e não uma amostragem aleatória simples como no caso da prevalência de focos em cada área.

A amostragem por cluster tende a aumentar a variância, ou seja, amplia o intervalo de confiança. Isso ocorre porque os elementos de um mesmo cluster tendem a ser mais semelhantes do que a população como um todo e acabam fornecendo menos informação sobre a população do que elementos de diferentes clusters. Portanto, as estimativas serão provavelmente menos precisas do que as estimativas obtidas através da amostragem aleatória simples. A estratificação tende a reduzir a variância e acaba compensando, pelo menos parcialmente, o efeito oposto da amostragem por clusters.

No cálculo da prevalência de focos no Estado de Santa Catarina, o efeito do desenho obtido foi 0,34 . Isso significa que a variância foi estimada como sendo 0,34 vezes a variância para uma amostra aleatória simples. Em outras palavras, isso quer dizer que, se a amostra do estudo fosse aleatória simples e comparássemos seu intervalo de confiança com o intervalo de confiança obtido no estudo, teríamos um intervalo de confiança maior se a amostra fosse aleatória simples, ou seja, o intervalo de confiança obtido no estudo é 0,34 vezes o intervalo de confiança da amostra aleatória simples. Este valor está subestimado em virtude do que foi 
descrito anteriormente em relação às prevalências de focos das áreas.

No cálculo da prevalência de animais soropositivos, os efeitos do desenho foram 4,13 para a área 4 e 4,39 para o Estado de Santa Catarina. Isso significa que, na área 4 a variância foi estimada como sendo 4,13 vezes a variância para uma amostra aleatória simples, ou seja, o intervalo de confiança obtido no estudo é 4,13 vezes o intervalo de confiança da amostra aleatória simples. Da mesma forma, a variância para o Estado de Santa Catarina foi estimada como sendo 4,39 vezes a variância para uma amostra aleatória simples.

A OIE reconhece como livre da brucelose bovina o país ou a zona que satisfaça as seguintes condições (OIE, 2003):

1) a brucelose bovina ou sua suspeita são de notificação obrigatória;

2) toda a população bovina está sob controle veterinário oficial e a freqüência de rebanhos infectados não excede 0,2\%;

3) os rebanhos são submetidos a testes sorológicos periódicos, independente da realização da prova do anel do leite;

4) a vacinação já foi totalmente abandonada há pelo menos três anos;

5) todos os animais soropositivos são abatidos;

6) só são introduzidos animais provenientes de rebanhos livres de brucelose.

Porém, considerando-se as dimensões do rebanho do Brasil, torna-se praticamente inviável ter toda a população bovina sob controle veterinário. Assim, seria conveniente que o Brasil propusesse à OIE uma estratégia diferente, ou seja, que a prevalência da brucelose pudesse ser estimada com base numa amostra e que um teste de hipóteses fosse utilizado para avaliar se a mesma estaria abaixo de $0,2 \%$.

Considerando essa possibilidade, no caso particular de Santa Catarina seria 
necessário um tamanho de amostra maior para se estimar de modo preciso a prevalência. Além disso, também seria necessário considerar o Estado de Santa Catarina como um todo, sem subdividi-lo em áreas. A estratégia consistiria em utilizar a amostragem aleatória simples para o cálculo da prevalência de focos no Estado de Santa Catarina, contornando as dificuldades de se estimar os intervalos de confiança. Para esse tipo de amostragem, é necessário calcular o número de propriedades que teriam que ser amostradas para que a diferença das prevalências $(0,02 \%$ [prevalência obtida no estudo] e 0,2\% [prevalência que deve ser alcançada para uma região ser considerada livre de brucelose]) seja significativa.

Para se ter uma idéia do número de amostras necessárias para este teste de hipóteses, considerando-se a prevalência que encontramos, ou seja, 0,02\% e um poder do teste igual a $80 \%$ (poder do teste é a probabilidade de rejeitar $\mathrm{H}_{0}$ quando $\mathrm{H}_{0}$ é falsa), seria necessária uma amostra de 3054 propriedades. Com um poder do teste de 90\%, seria necessária uma amostra de 3448 propriedades. No estudo realizado, foi utilizada uma amostra de 1579 propriedades.

A estratégia do PNCETB é associar medidas sanitárias compulsórias, através da vacinação de bezerras contra a brucelose e do controle do trânsito de animais destinados à reprodução, e ações de adesão voluntária, como a certificação de propriedades livres e de propriedades monitoradas (BRASIL, 2004).

Quando se alcançam $80 \%$ de cobertura vacinal e isso se mantém durante alguns anos, a prevalência será igual ou inferior a $2 \%$, freqüência que possibilita o incremento das ações de diagnóstico e sacrifício dos animais reatores (PAULIN; FERREIRA NETO, 2003).

$\mathrm{Na}$ fase em que o Estado de Santa Catarina se encontra, com 98,36\% das propriedades não vacinando seus animais e com a prevalência baixa, não há 
necessidade de se implantar a vacinação obrigatória.

O passo seguinte seria aumentar as ações de diagnóstico para a obtenção de propriedades livres. A eliminação das fontes de infecção, feita por meio de uma rotina de testes diagnósticos com sacrifício dos positivos, é a base das ações que visam à criação de propriedades livres da doença (BRASIL, 2004).

Pode-se dizer que a transição de área de controle para área de erradicação ocorre com o abandono da prática da vacinação e o aumento das ações de saneamento e certificação das unidades de criação por meio do sorodiagnóstico (PAULIN; FERREIRA NETO, 2003).

Apesar de Santa Catarina praticamente já ter abandonado a vacinação, $89,42 \%(87,80-90,89 \%)$ das propriedades analisadas não fazem o teste diagnóstico de brucelose. O diagnóstico é fundamental para a certificação de propriedades livres e monitoradas, onde todos os animais positivos são sacrificados. Portanto, é necessário intensificar a realização de testes diagnósticos nas propriedades para que se rastreie e se eliminem os animais positivos.

É importante lembrar que a erradicação da doença só é alcançada depois que a participação no programa se torna obrigatória. Além disso, e da baixa prevalência, que Santa Catarina já possui, um outro pré-requisito para que uma área seja considerada de erradicação é um bom serviço de sanidade animal, ou seja, um serviço que cubra de maneira satisfatória todo o território, aplique métodos de controle de qualidade dos procedimentos baseado em auditoria, implemente sistemas de vigilância ativos e passivos, rastreie focos de doença a partir do indivíduo, dispunha de equipe treinada em ações contingenciais e desfrute de prestígio perante os produtores e a população (PAULIN; FERREIRA NETO, 2003).

Para descobrir novos focos de brucelose em regiões onde a prevalência é 
muito baixa, como no caso de Santa Catarina, uma estratégia eficiente seria a implantação de sistemas de vigilância adaptados à realidade local (BRASIL, 2004).

O sistema de vigilância é muito útil para eliminar os resíduos de doença na fase de erradicação, por meio da detecção de rebanhos infectados (PAULIN; FERREIRA NETO, 2003).

Para alimentar o sistema de vigilância, propriedades de exploração de corte devem utilizar o sorodiagnóstico de animais de reprodução, cujas amostras seriam colhidas em locais como matadouros, leilões, exposições, rodeios e feiras. Em se tratando de propriedades leiteiras, devem utilizar a prova do anel do leite em amostras colhidas nas plataformas de recepção dos laticínios. Os rebanhos que forem identificados como positivos devem ser submetidos à sorologia individual (PAULIN; FERREIRA NETO, 2003).

Como em Santa Catarina a maioria das propriedades é familiar, outras formas devem ser utilizadas para alimentar o sistema de vigilância, como por exemplo, estudos por amostragem, que além de serem realizados para se conhecer a situação epidemiológica, detectam focos da doença.

Investigações de casos de aborto e de rumores da presença da doença também são eficientes na detecção de focos, principalmente quando se trata de propriedades que se mantêm informalmente no mercado de leite e de carne. A busca ativa de casos é muito importante nesses casos.

Todos os focos descobertos pelo sistema de vigilância devem ser saneados e transformados em propriedades livres. Investigações epidemiológicas retrospectivas e prospectivas devem ser realizadas a partir dos focos, pois assim é possível verificar a situação sanitária das propriedades que venderam ou compraram animais do foco. Importante lembrar que é necessário um bom sistema de informações e 
dados censitários pecuários de qualidade para que se tenha uma boa vigilância epidemiológica (PAULIN; FERREIRA NETO, 2003).

O Estado de Santa Catarina possui algumas características indicativas de que a transição de zona de controle para zona livre é iminente. A prevalência de focos de brucelose bovina é baixa e a maioria das propriedades não vacinam seus animais; o próximo passo é a obtenção da certificação de propriedades livres. Para isso é necessário o aumento de ações de diagnóstico e de saneamento e o fortalecimento do sistema de vigilância. Além disso, a realização de levantamentos amostrais periódicos auxiliaria o Estado de Santa Catarina a conseguir atingir a meta de se tornar zona livre de brucelose bovina. 


\section{Conclusão}

"A vida só pode ser compreendida olhando-se para trás; mas só pode ser vivida olbando-se para a frente." (Soren Kierkegaard) 


\section{CONCLUSÃO}

A prevalência de focos de brucelose bovina em fêmeas com idade igual ou superior a 12 meses é igual a 0,02\% (0,00-0,15\%) no Estado de Santa Catarina;

A prevalência de fêmeas com idade igual ou superior a 12 meses soropositivas para brucelose bovina é igual a 0,06\% (0,01-0,40\%) no Estado de Santa Catarina;

A prevalência de focos de brucelose bovina em fêmeas com idade igual ou superior a 12 meses é igual a 0,00\% (0,00-1,23\%) nas áreas 1 e 2 do Estado de Santa Catarina;

A prevalência de focos de brucelose bovina em fêmeas com idade igual ou superior a 12 meses é igual a 0,00\% (0,00-0,93\%) na área 3 do Estado de Santa Catarina;

- $\quad$ A prevalência de focos de brucelose bovina em fêmeas com idade igual ou superior a 12 meses é igual a 0,34\% (0,00-1,86\%) na área 4 do Estado de Santa Catarina;

A prevalência de focos de brucelose bovina em fêmeas com idade igual ou superior a 12 meses é igual a 0,00\% (0,00-1,26\%) na área 5 do Estado de 
Santa Catarina;

A prevalência de fêmeas com idade igual ou superior a 12 meses soropositivas para brucelose bovina é igual a 0,00\% (0,00-0,00\%) nas áreas 1, 2, 3 e 5 do Estado de Santa Catarina;

A prevalência de fêmeas com idade igual ou superior a 12 meses soropositivas para brucelose bovina é igual a 0,89\% $(0,13-5,76 \%)$ na área 4 do Estado de Santa Catarina;

A área 1 possui predominantemente exploração mista, criação extensiva, bovinos mestiços, mediana de 16 bovinos por propriedade, ordenha manual uma vez por dia, produção diária de 3,94 litros de leite por propriedade (mediana) e a maioria não resfria o leite e não utiliza inseminação artificial;

A área 2 possui predominantemente: exploração mista, criação extensiva, bovinos mestiços, mediana de 8 bovinos por propriedade, ordenha manual duas ou três vezes por dia, produção diária de 5 litros de leite por propriedade (mediana) e a maioria não resfria o leite e não utiliza inseminação artificial;

A área 3 possui predominantemente: exploração mista, criação extensiva, bovinos mestiços, mediana de 12 bovinos por propriedade, ordenha manual duas ou três vezes por dia, produção diária de 7,5 litros de leite por propriedade (mediana) e a maioria resfria o leite e não utiliza inseminação artificial; 
A área 4 possui predominantemente: exploração mista, criação extensiva, bovinos mestiços, mediana de 6 bovinos por propriedade, ordenha manual duas ou três vezes por dia, produção diária de 6 litros de leite por propriedade (mediana) e a maioria não resfria o leite e não utiliza inseminação artificial;

A área 5 possui predominantemente: exploração leiteira, criação extensiva, bovinos mestiços, mediana de 7 bovinos por propriedade, ordenha manual duas ou três vezes por dia, produção diária de 6 litros de leite por propriedade (mediana) e a maioria não resfria o leite e não utiliza inseminação artificial;

- $\quad$ De acordo com as análises realizadas, sugere-se que as áreas 3 e 4 sejam agrupadas. 


\section{Referências}




\section{REFERÊNCIAS}

ACHA, P. N.; SZYFRES, B. Brucelosis. In: ACHA, P. N.; SZYFRES, B. Zoonosis y enfermidades transmissibles comunes al hombre y a los animales. Washington: Organizacion Panamericana de la Salud, 1986. p. 14-35.

BATHKE, W. Brucelose. In: BEER, J. Doenças infecciosas em animais domésticos. São Paulo: Roca, 1988. v. 2, p. 163-178.

BRASIL. Ministério da Agricultura, Pecuária e Abastecimento. Departamento de Defesa Animal. Manual de procedimentos - Inquérito soroepidemiológico da brucelose. Brasília, 2001a.

BRASIL. Ministério da Agricultura, Pecuária e Abastecimento. Departamento de Defesa Animal. Programa Nacional de Controle e Erradicação da Brucelose e Tuberculose. Brasília, 2001b. Disponível em: <http://www.agricultura.gov.br>. Acesso em: 06 abr. 2002.

BRASIL. Ministério da Agricultura, Pecuária e Abastecimento. Departamento de Defesa Animal. Programa Nacional de Controle e Erradicação da Brucelose e Tuberculose - Manual técnico. Brasília, 2004.

CARTER, G. R.; CHENGAPPA, M. M. Essentials of veterinary bacteriology and mycology. 4 ed. Philadelphia: London, 1991. p. 196-201.

CHRISTIE, T. E. Eradication of brucellosis in Northern Ireland: field problems and experience. The Veterinary Record, v. 85, n. 10, p. 268-269, 1969.

COCHRAN, W. G. Sampling techniques. 3. ed. New York: John Wiley \& Sons,1977. $428 \mathrm{p}$.

CORREAA, O. Brucelose. In: CORREAA, O. Doenças infecciosas dos animais domésticos. Rio de Janeiro: Freitas Bastos, 1975. v. 1, p. 196-209.

CRAWFORD, R. P.; HUBER, J. D.; ADAMS, B. S. Epidemiology and surveillance. In: NIELSEN, K.; DUNCAN, J. R. Animal brucellosis. CRC Press, 1990. p. 131-151. 
DEAN, A. G.; DEAN, J. A.; COULOMBIER, D.; BRENDEL, K. A.; SMITH, D. C.; BURTON, A. H.; DICKER, R. C.; SULLIVAN, K.; FAGAN, R. F.; ARNER, T. G. Epi Info, version 6: a word processing, database, and statistics program for epidemiology on microcomputers. Atlanta: 1994. Centers for Disease Control and Prevention, $601 \mathrm{p}$.

FARIA, J. F. Situação da brucelose no Brasil. Comunicação Científica da Faculdade de Medicina Veterinária e Zootecnia da Universidade de São Paulo, São Paulo, v. 8, n. 2, p. 161-175, 1984.

GARCIA-CARRILO, C. La brucelosis de los animales en América y su relación con la infección humana. Paris: 1987. Office International des Epizooties, 303 p.

GODFROID, J. Brucellosis in wildlife . Rev. Sci. Tech. Office International des Epizooties, v. 21, n. 2, p. 277-286, 2002.

GRASSO, L. M. P. S. O combate à brucelose bovina. 2000. 112 f. Dissertação (mestrado) - Faculdade de Medicina Veterinária e Zootecnia, Universidade de São Paulo, São Paulo, 2000.

ITO, F. H.; VASCONCELLOS, S. A.; BERNARDI, F.; NASCIMENTO, A. A.; LABRUNA, M. B.; ARANTES, I. G. Evidência sorológica e brucelose e leptospirose e parasitismo por ixodídeos em animais silvestres do Pantanal sul-matogrossense. Ars Veterinária, Jaboticabal, v. 14, n. 3, p. 302-310, 1998.

LYRA, T. M. P. Epidemiologia da brucelose. Comunicação Científica da Faculdade de Medicina Veterinária e Zootecnia da Universidade de São Paulo, São Paulo, v. 8, n. 2, p. 177-186, 1984.

MINITAB. Minitab release 14.1. Minitab Inc., 2003.

NICOLETTI, P. Brucelose - as técnicas de controle. Imagem Rural Leite, v. 5, n. 53, p. 9-12, 1998.

O'CONNOR, M. Brucellosis - progress and problems (Republic of Ireland). The Veterinary Record, v. 92, n. 1, p. 18-19, 1973.

OFFICE INTERNATIONAL DES EPIZOOTIES. Terrestrial animal health code. $11^{\text {th }}$ 
ed., 2003. Disponível em: <http://www.oie.int/eng/normes/MCode/A summry.htm>. Acesso em: 27 fev. 2004.

OMER, M. K.; SKJERVE, E.; WOLDEHIWET, Z.; HOLSTAD, G. Risk factors for Brucella spp. infection in dairy cattle farms in Asmara, State of Eritrea. Preventive Veterinary Medicine, v. 46, p. 257-265, 2000.

PAULIN, L. M.; FERREIRA NETO, J. S. A experiência brasileira no combate à brucelose bovina. Arquivos do Instituto Biológico, São Paulo, v. 69, n. 2, p. 105112, 2002.

PAULIN, L. M.; FERREIRA NETO, J. S. O combate à brucelose bovina: situação brasileira, Jaboticabal: Funep, 2003. 154 p.

POESTER, F. P.; GONÇALVES, V. S. P.; LAGE, A. P. Brucellosis in Brazil. Veterinary Microbiology, v. 90, p. 55-62, 2002.

SALMAN, M. D.; MEYER, M. E. Epidemiology of bovine brucellosis in the Mexicali Valley, Mexico: literature review of disease-associated factors. American Journal of Veterinary Research, v. 45, n. 8, p. 1557-1560, 1984.

SALMAN, M. D.; MEYER, M. E.; CRAMER, J. C. Epidemiology of bovine brucellosis in the Mexicali Valley, Mexico: results of path analysis. American Journal of Veterinary Research, v. 45, n. 8, p. 1567-1571, 1984.

SALMAN, M. D.; MEYER, M. E.; HIRD, D. W. Epidemiology of bovine brucellosis in the Mexicali Valley, Mexico: data gathering and survey results. American Journal of Veterinary Research, v. 45, n. 8, p. 1561-1566, 1984.

SANTA CATARINA. Estratégia de ação para inquérito epidemiológico da brucelose na espécie bovina. Santa Catarina: Secretaria de Estado do Desenvolvimento Rural e da Agricultura. Companhia Integrada de Desenvolvimento Agrícola de Santa Catarina, 2001.

SÃO PAULO. Coordenadoria de Defesa Agropecuária do Estado de São Paulo. Secretaria de Agricultura e Abastecimento. Brucelose. São Paulo, 2002. Disponível em: <http://www.cda.sp.gov.br/Programas/BruTb/doencas/BRU/index.htm>. Acesso em: 25 jan. 2003.

SIEGEL, S. Estatística não-paramétrica. São Paulo: McGraw-Hill, 1975. 350 p. 
SPSS. SPSS base 9.0 user's guide. Chicago, 1999. 740 p.

GAJJAR, Y.; MEHTA, C.; PATEL, N.; SENCHAUDHURI, P. StatXact 3 for Windows user manual. Cambridge, 1997. $788 \mathrm{p}$.

THRUSFIELD, M. Veterinary epidemiology. 2 ed. Cambridge: Blackwell Science, 1995. $479 \mathrm{p}$.

VASCONCELLOS, S. A.; ITO, F. H.; CÔRTES, J. A. Bases para a prevenção da brucelose animal. Comunicação Científica da Faculdade de Medicina Veterinária e Zootecnia da Universidade de São Paulo, São Paulo, v. 11, n. 1, p. 25-36, 1987.

ZAR, J. H. Biostatistical analysis. 3 ed. New Jersey: Prentice Hall, 1996. 662 p. 
Apêndice 
APÊNDICE A - Quadro comparativo apresentando as semelhanças existentes entre as cinco áreas do Estado de Santa Catarina

\begin{tabular}{|c|c|c|c|c|c|}
\hline VARIÁVEIS & ÁREA 1 & ÁREA 2 & ÁREA 3 & ÁREA 4 & ÁREA 5 \\
\hline exploraçao corte & & expl corte & expl corte & expl corte & \\
\hline exploraçao leite & & & expl leite & expl leite & \\
\hline exploraçao mista & expl mista & & expl mista & expl mista & \\
\hline criação extensiva & & extensiva & extensiva & extensiva & \\
\hline criação semi-confinada & & semi-conf & semi-conf & semi-conf & \\
\hline \multicolumn{6}{|l|}{ criação confinada } \\
\hline \multicolumn{6}{|l|}{ bovino europeu corte } \\
\hline bovino mestiço & mestiço & mestiço & mestiço & mestiço & mestiço \\
\hline bovino europeu leite & & & europ leite & europ leite & europ leite \\
\hline bovino zebuíno & zebuínos & zebuínos & zebuínos & & zebuínos \\
\hline ordenha manual & & ord manual & ord manual & ord manual & ord manual \\
\hline ordenha sala ordenha & sala ord & sala ord & sala ord & sala ord & sala ord \\
\hline ordenha mecânica ao pé & & ord mec pé & & ord mec pé & ord mec pé \\
\hline ordenha 1 vez/dia & & $1 \mathrm{vez} / \mathrm{dia}$ & $1 \mathrm{vez} / \mathrm{dia}$ & $1 \mathrm{vez} / \mathrm{dia}$ & 1 vez/dia \\
\hline ordenha 2 ou 3 vezes/dia & & 2 ou 3/dia & & 2 ou 3/dia & \\
\hline \multirow[t]{2}{*}{ produção diária leite } & & prod leite & prod leite & prod leite & prod leite \\
\hline & & & & prod leite & prod leite \\
\hline resfriamento leite & resfr leite & resfr leite & & resfr leite & resfr leite \\
\hline não usa IA & & & não usa IA & & não usa IA \\
\hline IA + touro & & $\mathrm{IA}+$ touro & $\mathrm{IA}+$ touro & $\mathrm{IA}+$ touro & $\mathrm{IA}+$ touro \\
\hline só IA & só IA & & & só IA & \\
\hline \multirow[t]{2}{*}{ total bovinos } & & total bov & & & total bov \\
\hline & & & & total bov & total bov \\
\hline \multirow[t]{2}{*}{ machos castrados } & m castr & m castr & m castr & m castr & \\
\hline & & m castr & & m castr & m castr \\
\hline \multirow[t]{2}{*}{ machos 0-6 meses } & $\mathrm{m} \mathrm{0-6m}$ & $\mathrm{m} \mathrm{0-6m}$ & & $\mathrm{m} \mathrm{0-6m}$ & $\mathrm{m} \mathrm{0-6m}$ \\
\hline & & $\mathrm{m} \mathrm{0-6m}$ & m 0-6m & & $\mathrm{m} \mathrm{0-6m}$ \\
\hline \multirow[t]{2}{*}{ machos 6-12 meses } & m 6-12m & $m 6-12 m$ & m 6-12m & & m 6-12m \\
\hline & m 6-12m & & & m 6-12m & m 6-12m \\
\hline \multirow[t]{2}{*}{ machos > 12 meses } & $m>12 m$ & & $m>12 m$ & $m>12 m$ & $m>12 m$ \\
\hline & $m>12 m$ & $m>12 m$ & & & $m>12 m$ \\
\hline fêmeas 0-6 meses & f $0-6 m$ & f $0-6 m$ & f $0-6 m$ & f $0-6 m$ & f $0-6 m$ \\
\hline fêmeas 6-12 meses & f $6-12 m$ & f $6-12 m$ & f $6-12 m$ & & f $6-12 m$ \\
\hline \multirow{2}{*}{ fêmeas > 12 meses } & & & $f>12 m$ & $f>12 m$ & $f>12 m$ \\
\hline & $f>12 m$ & & & $f>12 m$ & \\
\hline
\end{tabular}

Nota: As linhas assinaladas com cores iguais indicam que as respectivas áreas são estatisticamente iguais em relação às variáveis correspondentes. 
Anexo 


\begin{tabular}{|c|c|c|c|c|c|c|c|c|c|c|c|c|c|}
\hline \multicolumn{10}{|c|}{32 - INFORMAÇÕES SOBRE AS AMOSTRAS COLHIDAS } & \multicolumn{4}{|c|}{33 - RESULTADOS LABORATORIAIS (3) } \\
\hline $\mathbf{N}^{0}$ & $\begin{array}{l}\text { NÚMERO DO FRASCO } \\
\text { Cód. do estudo + No sequêncial } \\
(\mathbf{1 0} \text { dígitos) }\end{array}$ & $\begin{array}{c}\text { Espécie } \\
\text { (1) }\end{array}$ & $\begin{array}{l}\text { Idade } \\
\text { (anos) }\end{array}$ & $\begin{array}{c}\mathrm{N}^{\circ} \mathrm{de} \\
\text { parições }\end{array}$ & \begin{tabular}{c}
\multicolumn{2}{c}{ Já } \\
Abortou? \\
SIM NÂO
\end{tabular} & BRU. & $\begin{array}{l}\text { VACI } \\
\text { LEP. }\end{array}$ & $\begin{array}{r}\text { AS (2) } \\
\text { IBR }\end{array}$ & BVD & $\begin{array}{c}\text { AAT } \\
(-) \text { ou (+) }\end{array}$ & $\begin{array}{c}\text { SAL } \\
\text { (Título) }\end{array}$ & $\begin{array}{c}\text { 2-ME } \\
\text { (Título) }\end{array}$ & $\begin{array}{c}\text { Resultado Final } \\
\text { (NEG) (INC) (POS) }\end{array}$ \\
\hline 1 & & & & & & & & & & & & & \\
\hline 2 & & & & & & & & & & & & & \\
\hline 3 & & & & & & & & & & & & & \\
\hline 4 & & & & & & & & & & & & & \\
\hline 5 & & & & & & & & & & & & & \\
\hline 6 & & & & & & & & & & & & & \\
\hline 7 & & & & & & & & & & & & & \\
\hline 8 & & & & & & & & & & & & & \\
\hline 9 & & & & & & & & & & & & & \\
\hline 10 & & & & & & & & & & & & & \\
\hline 11 & & & & & & & & & & & & & \\
\hline 12 & & & & & & & & & & & & & \\
\hline 13 & & & & & & & & & & & & & \\
\hline 14 & & & & & & & & & & & & & \\
\hline 15 & & & & & & & & & & & & & \\
\hline
\end{tabular}

Códigos e instrucões para preenchimento desta tabela

(1) Bovino = 1; Bubalino $=2$

(2) Marcar com X nas vacinas utilizadas (Bru = Brucelose; Lep = Leptospirose; IBR = Rinotraqueíte infecciosa bovina; BVD = Diarréia viral dos bovinos)

(3) O resultado do Antígeno Acidificado Tamponado (AAT) pode ser : sem aglutinação ( - ) ou com algutinação ( + ); a prova confirmatória (2-ME) deve ser feita em soros reagentes (+) ao AAT, executando simultãneamente a Soroaglutinação Lenta (SAL) e o 2-ME; o resultado final pode ser Negativo (NEG), Inconclusivo (INC) ou Positivo (POS), de acordo com a tabela de interpretação oficial, que consta do Capítulo VI, do Regulamento Técnico do Programa Nacional de Controle e Erradicação da Brucelose e Tuberculose Animal. 